\title{
Recent developments in the preparation, characterization and applications of glass- and glass-ceramic-to-metal seals and coatings
}

\author{
I. W. Donald • P. M. Mallinson - B. L. Metcalfe • \\ L. A. Gerrard · J. A. Fernie
}

Received: 19 August 2010/Accepted: 17 November 2010/Published online: 6 January 2011

(C) Springer Science+Business Media, LLC 2011

\begin{abstract}
There has, in recent years, been a major revival of interest in glass- and glass-ceramic-to-metal seals and coatings for new applications. Experience dictates that many factors need to be taken into consideration in the successful design and manufacture of high-quality seals, particularly if an adequate component lifetime is to be achieved. For example, during their preparation, undesirable reactions may occur between diffusing metal species and glass constituents, and these can lead to the formation of highly localized internal stresses, which can initiate failure of a seal either during manufacture or, more seriously, whilst in service due to the influence of static fatigue. In the case of high-temperature systems, reactions under hostile operating conditions also need to be taken into consideration. In this review, the factors learnt from past experience that influence the formation and lifetime behaviour of glass and glass-ceramic/metal systems are briefly introduced, and their relevance to the newer applications including solid oxide fuel cell sealants and coatings on titanium for biomedical applications is discussed.
\end{abstract}

\section{Introduction}

That glass, under suitable conditions, will bond well to a wide variety of metals and alloys has long been recognized, and this has led to the development of many useful products [1]. It was subsequently demonstrated that superior products can be manufactured using glass-ceramic

I. W. Donald · P. M. Mallinson ( $₫) \cdot$ B. L. Metcalfe

L. A. Gerrard - J. A. Fernie

Materials Science Research Division, AWE,

Aldermaston, Berkshire, UK

e-mail: phillip.mallinson@awe.co.uk materials [2], and many applications have also been found for these [1]. Glass-ceramics combine the generally superior properties of crystalline ceramics with the ease of processing of glass [3, 4]. Major attributes of glassceramics include more refractory behaviour and superior mechanical properties, relative to glass, coupled with good bonding characteristics to metals, with one of the major qualities being an ability to tailor their thermal expansion characteristics. This makes glass-ceramics in particular ideal candidates for sealing and coating applications where compatible thermal expansions are essential.

There has, in recent years, been a major revival of interest in glass- and glass-ceramic-to-metal seals and coatings for new applications; for example, complex miniature and light-weight electrical and electronic components, high-temperature sealants in solid oxide fuel cells, SOFC, and seals and coatings to $\mathrm{Ti}$ and its alloys for biomedical applications [1]. This renewed interest and potential use of glass-ceramics in advanced applications makes it timely to review recent developments and to revisit our understanding of the factors that can influence component quality. This article reviews the new advancements in glass and glass-ceramic/metal seal systems with particular reference to SOFCs, other high-temperature seal applications and seals to titanium and its alloys primarily for biomedical applications. Factors that can affect the lifetime behaviour of these systems are reviewed from past and recent experience, with particular emphasis given to the influence of interfacial reactions on seal quality and lifetime behaviour. Steps that can be taken to enhance lifetime behaviour through control of these reactions are outlined and discussed. Recent studies on sealing to the pure metals $\mathrm{Fe}, \mathrm{Ni}$ and $\mathrm{Cr}$ are also covered, this work being aimed at gaining a better understanding of the diffusion and reaction behaviour of individual metallic species found in 
common practical alloy systems including stainless steels and Ni-based superalloys.

\section{Practical aspects of glass- and glass-ceramic-to-metal component design and manufacturing technologies}

Glass- and glass-ceramic-to-metal bonding

Glass-to-metal bonding is traditionally a fusion technique with the glass melted in contact with the metal parts to be joined or sealed to. On melting the glass, it is allowed to flow into the metal parts where it wets the surface and reacts to form an interface [1]. In the case of glass-ceramic-to-metal seals, the melting stage is usually followed by a two-stage nucleation and crystallization sequence to form a glass-ceramic material with thermal expansion characteristics ideally matched to those of the metal parts. In general, the same crystalline phases are produced regardless of whether the glass-ceramic is prepared as part of a seal or is made as a bulk material using the standard nucleation and crystallization stages. Sometimes, however, following a sealing cycle does not produce the same results as the conventional two-stage heat treatment, and therefore it should never be assumed that the properties of a bulk glass-ceramic will be the same as those produced as part of a seal or coating $[1,5]$. When choosing a specific glassceramic for a seal application, it is therefore best practice that a simulated sealing cycle is employed in the initial development process.

\section{Design of seals and joints}

Historically, glass-to-metal seals have been assigned to one of four major types [6]: matched thermal expansion seals, unmatched expansion seals, soldered seals and mechanical joints, although the latter two are hardly ever practiced today. The importance of design should not, however, be underestimated. Bad design is usually associated in particular with any mismatch in coefficient of thermal expansion producing tensile stresses in the glass/ceramic component. These usually manifest themselves as cracks emanating from the interface into the bulk of the glass/ ceramic, although if the stresses are not high enough to cause cracking initially, time-dependent failure may occur due to the influence of static fatigue. A good design takes consideration of any possible mismatch in thermal expansion and seeks to place the interface in compression [7]. When designing components it is therefore important to understand the relationship between the physical properties of the bulk materials, the potential for any interfacial reactions and the final stress state of the bonded component, as discussed in the next section.
Ageing mechanisms and factors affecting the lifetime behaviour of glass- and glass-ceramic-to-metal seals

Many additional factors need to be taken into consideration in the successful design and manufacture of high-quality glass-ceramic-to-metal seals if adequate lifetime behaviour is to be achieved [1]. For example, in order for a glassceramic to form a mechanically strong, adherent and if necessary hermetic seal to a metal or alloy a number of specific criteria must be met, as discussed below.

Thermal expansion mismatch and interfacial reactions

To remain hermetic and/or mechanically robust, a seal must exhibit strong bonding at the interface. It is also recognized that residual stresses must be kept as low as possible and must be predominantly compressive in nature, in order to prevent the formation of undesirable tensile stresses in the seal after cooling from the fabrication temperature or during subsequent thermal cycling. This requires that not only the thermal expansion characteristics of the metal and bulk glass-ceramic are closely matched, but also that interfacial reactions are kept to a minimum and do not lead to the formation of reaction products and precipitated phases with thermal expansion or elastic characteristics that differ markedly from those of the bulk phases, the formation of which may lead to unacceptably high residual stresses within the interfacial reaction zone. In addition, reaction between diffusing metallic species and glass constituents, including the nucleating agents employed for specific glass-ceramic systems, must be avoided [1, 3, 4, 8, 9]. One example of an undesirable reaction is that which may occur between $\mathrm{Fe}$ or $\mathrm{Cr}$, a constituent of many common metallic alloys, and $\mathrm{P}_{2} \mathrm{O}_{5}$, employed as a nucleating agent in various glass-ceramic systems, leading to the formation of iron and/or chromium phosphide precipitates within the interfacial region [1].

$22(\mathrm{Cr} / \mathrm{Fe})+3 \mathrm{P}_{2} \mathrm{O}_{5} \rightarrow 6(\mathrm{Cr} / \mathrm{Fe})_{2} \mathrm{P}+5(\mathrm{Cr} / \mathrm{Fe})_{2} \mathrm{O}_{3}$

$9(\mathrm{Cr} / \mathrm{Fe})+\mathrm{P}_{2} \mathrm{O}_{5} \rightarrow 2(\mathrm{Cr} / \mathrm{Fe})_{2} \mathrm{P}+5(\mathrm{Cr} / \mathrm{Fe}) \mathrm{O}$

Any reactions that do occur may reduce the effectiveness of the nucleating agent, and this can result in the formation of a coarse microstructure in the interfacial region, or a region with a high-proportion of residual glass. In either case, the thermal expansion characteristics in the interfacial region will differ from those of the bulk glass-ceramic and this will again lead to the generation of highly localized residual stresses which, if high enough, may lead to failure of a seal by de-bonding at the interface or by fracture through the glassceramic, either during manufacture or shortly afterwards; however, even if the residual stresses are not high enough to initiate cracking in the short term, they may, in the longer 
term, give rise to delayed failure as a result of thermal cycling and/or due to the influence of static fatigue. Any mismatch in thermal expansion between the glass-ceramic and the metal is therefore expected to play a significant contribution to the lifetime behaviour of seal components.

Clearly, a thorough understanding of the relevant glassceramic/metal interactions is therefore essential in order that steps can be taken to avoid, or at least minimize, reactions within the interfacial region that may lead to localized modifications of the glass-ceramic microstructure. Failure of the metallic components very rarely occurs because stresses can normally be accommodated by plastic flow of the metal.

\section{Influence of water}

Another factor which may influence the lifetime behaviour of a seal component involves the presence of water in the starting glass. Normal glass can contain not insignificant quantities of dissolved water, typically $0.02-0.06$ mass\%. It was noted by Haws et al. [10] that this can affect seal quality through thermodynamically favourable reactions between the water and diffusing metallic species, in particular $\mathrm{Cr}$, to yield hydrogen gas (at $1300 \mathrm{~K}$ ):

$$
\begin{array}{r}
\mathrm{Cr}+3 / 2 \mathrm{H}_{2} \mathrm{O} \rightarrow 1 / 2 \mathrm{Cr}_{2} \mathrm{O}_{3}+3 / 2 \mathrm{H}_{2} \uparrow \\
\left(\Delta \mathrm{G}^{\mathrm{o}}=-129 \mathrm{~kJ} / \text { mole }\right)
\end{array}
$$

It was observed that seals prepared using starting glass with higher dissolved water contents contained more bubbles, but that a number of methods could be used to minimize the deleterious influence of water. These included melting under dry conditions; for example, by bubbling dry gas through the melt; and/or using dry starting constituents or materials low in water, e.g. $\mathrm{Li}_{3} \mathrm{PO}_{4}$ as a source of $\mathrm{P}_{2} \mathrm{O}_{5}$ in preference to $\mathrm{NH}_{4} \mathrm{H}_{2} \mathrm{PO}_{4}$; or by use of specific additives that would react preferentially with $\mathrm{Cr}$ during seal manufacture, e.g. $\mathrm{CuO}$ :

$$
\begin{array}{r}
\mathrm{Cr}+3 \mathrm{CuO} \rightarrow 1 / 2 \mathrm{Cr}_{2} \mathrm{O}_{3}+3 / 2 \mathrm{Cu}_{2} \mathrm{O} \\
\left(\Delta \mathrm{G}^{\mathrm{o}}=-381 \mathrm{~kJ} / \text { mole }\right)
\end{array}
$$

In addition to $\mathrm{Cr}$, reaction of water with many other metals commonly found in commercial alloys is also thermodynamically favourable; for example (at $1300 \mathrm{~K}$ ):

$$
\begin{gathered}
\mathrm{Y}+3 / 2 \mathrm{H}_{2} \mathrm{O} \rightarrow 1 / 2 \mathrm{Y}_{2} \mathrm{O}_{3}+3 / 2 \mathrm{H}_{2} \uparrow \\
\left(\Delta \mathrm{G}^{\mathrm{o}}=-501 \mathrm{~kJ} / \text { mole }\right) \\
\mathrm{Ti}+2 \mathrm{H}_{2} \mathrm{O} \rightarrow \mathrm{TiO}_{2}+2 \mathrm{H}_{2} \uparrow\left(\Delta \mathrm{G}^{\mathrm{o}}=-355 \mathrm{~kJ} / \mathrm{mole}\right) \\
\mathrm{Ta}+5 / 2 \mathrm{H}_{2} \mathrm{O} \rightarrow 1 / 2 \mathrm{Ta}_{2} \mathrm{O}_{5}+5 / 2 \mathrm{H}_{2} \uparrow \\
\left(\Delta \mathrm{G}^{\mathrm{o}}=-298 \mathrm{~kJ} / \text { mole }\right)
\end{gathered}
$$

Seals and coatings containing bubbles are not only weakened mechanically, but their lifetime behaviour will also be affected through the generation of enhanced fracture paths.

\section{Early studies on sealing glass and glass-ceramics to specific metal alloy systems}

Experience gained from earlier studies, including the influences noted in "Ageing mechanisms and factors affecting the lifetime behaviour of glass- and glass-ceramic-to-metal seals" section, should not be overlooked when designing new systems, as many lessons have been learnt in the past of direct relevance to new and future developments. Some additional earlier studies of relevance to new and future investigations are covered below.

Fe-based alloys

The thermal expansion of Fe-based alloys covers a very wide range from $<3 \times 10^{-6} / \mathrm{K}$ over limited temperature ranges for some binary $\mathrm{Fe}-\mathrm{Ni}$ alloys to $>18 \times 10^{-6} / \mathrm{K}$ for some stainless steels. A wealth of early information exists on the vitreous (porcelain) enamelling of iron-based alloys [11] to which the reader should refer to for an historical perspective. In the case of glass-ceramic coatings, it has been noted that pre-oxidation of mild steel in air can give rise to non-stoichiometric $\mathrm{FeO}$. On forming a seal, rapid diffusion of $\mathrm{Fe}^{2+}$, which is a glass modifier and is highly soluble and mobile, can lead to the formation of a diffusion gradient and a corresponding variation in thermal expansion within the interface [12]. This in turn gives rise to a stress gradient which is likely to be detrimental to the lifetime behaviour of this system. In view of the high solubility of $\mathrm{Fe}^{2+}$, careful control over the processing conditions and sealing atmosphere is required in order to achieve a satisfactory product, with formation of $\mathrm{Fe}_{2} \mathrm{O}_{3}$ rather than $\mathrm{FeO}$ being favoured. This highlights the need to ensure the formation of an appropriate substrate oxide in any sealing operation; i.e. an oxide exhibiting limited solubility and diffusion into the glass sealant.

Both lithium zinc silicate (LZS) and lithium aluminosilicate (LAS) glass-ceramics have been successfully sealed to a number of different alloys in the manufacture of electrical feed-through components [1,5]. It was observed that extensive interfacial reactions may occur during this process to give a variety of precipitated products, as illustrated in Fig. 1. Expanding on Haws' work, it has been found that the influence of transition metal oxide additions to the starting glass can exert a very beneficial dual effect on the interfacial chemistry, not only by minimizing the undesirable effects of water reactions, but also by reducing the detrimental effects of reactions between diffusing metal species and glass-ceramic constituents to form undesirable 


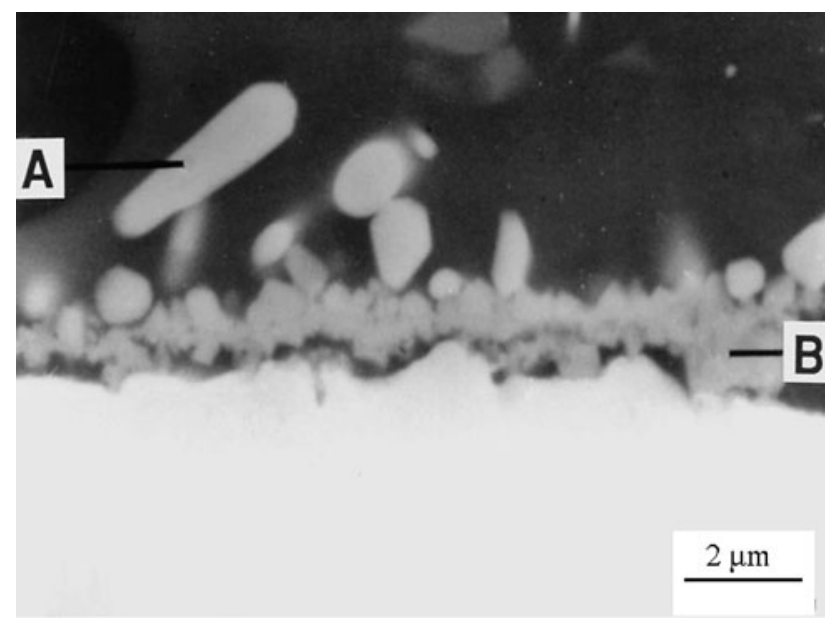

Fig. 1 Seal between LZS glass-ceramic and stainless steel. Note the presence of iron phosphide precipitates $(A)$ and a chromium siliciderich interface $(B)$

precipitated phases. For example, the reaction between $\mathrm{CuO}$ in the glass and $\mathrm{Cr}$ or $\mathrm{Fe}$ diffusing into the interfacial region is more favourable thermodynamically than the reactions between $\mathrm{Cr}$ and $\mathrm{Fe}$ with the glass nucleating agent, $\mathrm{P}_{2} \mathrm{O}_{5}$.

Addition of $\mathrm{CuO}$ to the starting glass is therefore particularly beneficial, leading to a relatively thin oxide layer and a total absence of precipitated phases, as seen in Fig. 2, which shows a seal between stainless steel and LZS glass containing a $2 \mathrm{~mol} \% \mathrm{CuO}$ addition. It may be concluded that use of specific additives presents a particularly useful and relatively straightforward method by which to modify the interfacial chemistry of glass or glass-ceramic/metal systems.

In addition to composition modification it is also possible in some instances to influence the resulting interfacial

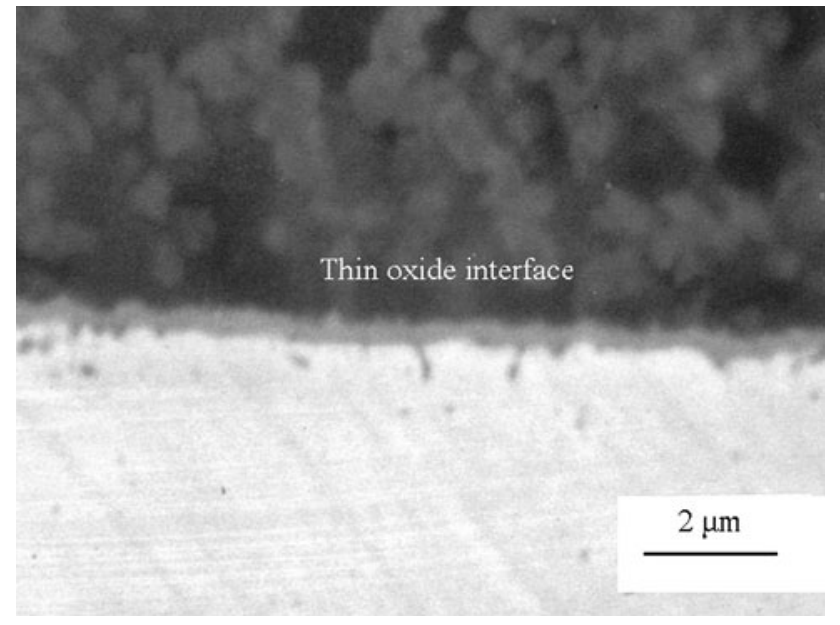

Fig. 2 As Fig. 1 but with starting glass containing $\mathrm{CuO}$ additive. Note the absence of interaction products and a thin chromium oxiderich interface chemistry simply by changing the heat-treatment schedule, although it should be appreciated that this is only viable if the thermal expansion of the glass-ceramic is not adversely affected by such a change. In many instances this will not be feasible because the thermal expansion behaviour of a given glass-ceramic may be very dependent not only on the precise crystallization temperature but also on the actual sealing temperature, and there may only be relatively narrow processing windows which yield the required expansion characteristics $[1,5]$. In other cases, pre-oxidation of the metal prior to sealing may also influence the diffusion of undesirable metallic species from the substrate, as illustrated by Fig. 3. All of these factors need to be taken into account in the preparation of a suitable seal.

Ni-based superalloys

Nickel-based superalloys cover a more limited thermal expansion range from $<12 \times 10^{-6} / \mathrm{K}$ for Hastelloy B2 to $>16 \times 10^{-6} / \mathrm{K}$ for Inconel 718 . As reviewed by Donald, extensive work has been reported on the sealing of glassceramics to a variety of Ni-based superalloys $[1,5]$. For example, Hong and Holland [13] noted that in the absence of a pre-oxidation stage, glass-ceramic coatings on Nimonic 263 alloy were coarse grained. This was believed to be caused by the formation of $\mathrm{CrO}$ at the interface followed by reaction of diffusing $\mathrm{Cr}^{2+}$ with the $\mathrm{P}_{2} \mathrm{O}_{5}$ nucleating agent. On the other hand, pre-oxidation of the substrate yielded $\mathrm{Cr}$ in the $\mathrm{Cr}^{3+}$ oxidation state, which is considerably less mobile than $\mathrm{Cr}^{2+}$, and therefore reaction with $\mathrm{P}_{2} \mathrm{O}_{5}$ was avoided, resulting in a fine grained microstructure. In studies by Donald [1,5], a variety of Ni-based superalloys have been sealed to a lithium zinc silicate glass-ceramic. Particularly good seals were achieved to Hastelloy C276 alloy, as seen in Fig. 4. It is again clear that

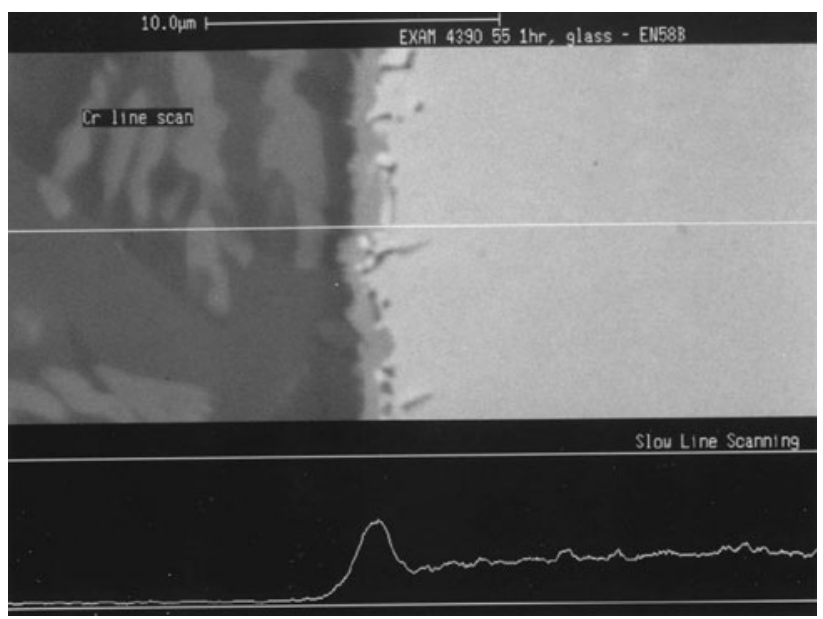

Fig. 3 As Fig. 1 but bonding to pre-oxidized stainless steel. EDS line scans for $\mathrm{Cr}$ 


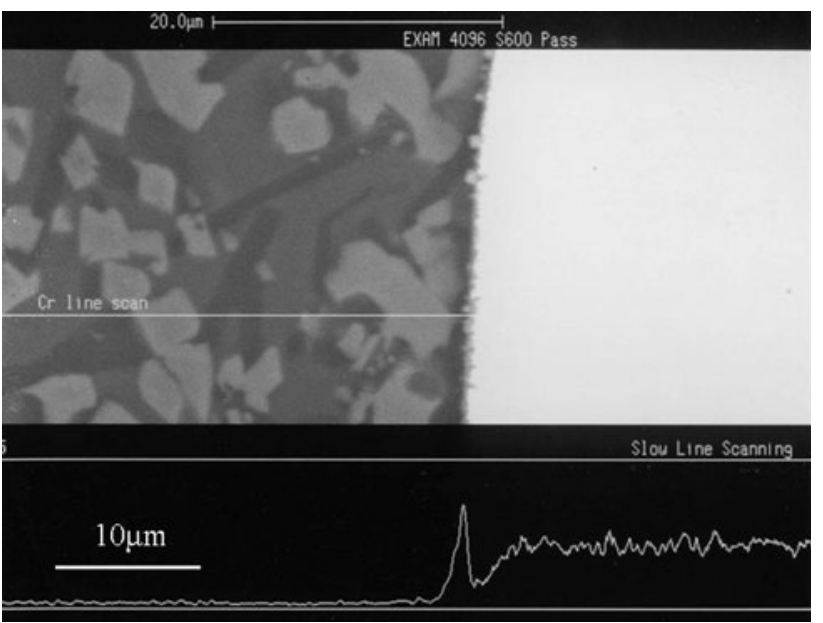

Fig. 4 Seal between LZS glass-ceramic and Hastelloy C276 alloy. EDS line scan for $\mathrm{Cr}$

many factors need to be taken into account in the preparation of a suitable seal and whether or not to pre-oxidize may not be a straightforward question.

\section{Ti and Ti-based alloys}

The initial impetus for research into $\mathrm{Ti}$ and its alloys was provided by a demand in the 1950s for new materials with high strength to weight ratios for the aerospace industry. Its major use is still within the aerospace industry for both engine and airframe parts $[14,15]$. Chemically, Ti metal is relatively reactive; for example, it is pyrophoric when finely divided. In bulk form, however, it is remarkably resistant to chemical corrosion due to the formation of a dense, adherent and self-healing oxide film. The resistance to corrosion provides the second major use of $\mathrm{Ti}$ in the chemical industry where high-corrosion-resistance is required [16-18]. The final major use is for orthopaedic implants where the mechanical properties, inertness and non-toxic behaviour of Ti combine to make it a reasonably acceptable biomaterial [19].

The thermal expansion of pure $\mathrm{Ti}$ is $9.2 \times 10^{-6} / \mathrm{K}$ over the range $0-860{ }^{\circ} \mathrm{C}$, but it undergoes an $\alpha$-to- $\beta$-phase transformation at $882{ }^{\circ} \mathrm{C}$, from a low-temperature hcp phase to a high-temperature bcc phase, and this is accompanied by a significant volume change. Alloying with other metals to form solid solutions can stabilize either the $\alpha$ - or $\beta$-phase. The $\alpha$-phase exhibits greater toughness and fatigue resistance, whilst the $\beta$-phase offers superior creep resistance. Mixed $\alpha / \beta$ alloys provide a useful compromise of properties and include the widely used Ti6Al4V alloy with a thermal expansion of $9.1-9.8 \times 10^{-6} / \mathrm{K}$.

There are three important factors to consider which make the development of a glass- or glass-ceramic-to-metal seal involving $\mathrm{Ti}$ a significant challenge. First is the formation of an oxide scale with a brittle sub-surface layer which can result in surface cracking; this limits the service temperature of titanium and its alloys to approximately $590{ }^{\circ} \mathrm{C}$ in air. The second factor involves the allotropic phase transition at $882{ }^{\circ} \mathrm{C}$; therefore, either a low-sealing temperature or a phase stabilized alloy is required. The third factor is the high reactivity of titanium with respect to the glass, and this can result in severe interfacial reactions.

Some of the early studies on sealing to Ti alloys, from which important knowledge has been gained, include the following.

\section{Silicate-based glasses}

A variety of glass compositions have been investigated for sealing to titanium, as summarized in Table 1. It has been noted that high-quality seals to titanium and its alloys cannot generally be achieved using conventional silicate sealing glasses [1]. The predominant cause of this is the occurrence of interfacial reactions between the $\mathrm{Ti}$ and the glass. The free energy of oxidation of Ti is very low $\left(\Delta G^{0}\right.$ at $1273 \mathrm{~K}$ is $-677.8 \mathrm{~kJ} / \mathrm{mol}$ ), making Ti very susceptible to oxidation by the glass under sealing conditions. A study of the Ti-Si-O system at $1373 \mathrm{~K}$ by Goldstein et al. [20] has shown $\mathrm{SiO}_{2}$ to be in equilibrium with $\mathrm{TiO}_{2}, \mathrm{Ti}_{5} \mathrm{Si}_{3}$ and $\mathrm{TiSi}$. Sealing of $\mathrm{Ti}$ to a silicate-based glass typically leads to the following reaction:

$8 \mathrm{Ti}_{(\text {metal })}+3 \mathrm{SiO}_{2 \text { (glass) }} \rightarrow \mathrm{Ti}_{5} \mathrm{Si}_{3 \text { (interface) }}+3 \mathrm{TiO}_{2 \text { (interface) }}$.

The reactions between titanium and glass have been reported in a number of studies. For example, Passerone et al. [21] investigated the reaction between $\mathrm{Ti}$ and molten sodium disilicate glass at $1100-1400{ }^{\circ} \mathrm{C}$. The effect of doping with $\mathrm{TiO}_{2}$ and $\mathrm{La}_{2} \mathrm{O}_{3}$ on sealing behaviour was also assessed. They observed the formation of a $\mathrm{Ti}_{5} \mathrm{Si}_{3}$ intermetallic phase, as would be expected, and noted that this forms a eutectic with $\mathrm{Ti}$ at $1330{ }^{\circ} \mathrm{C}$, whilst at higher temperatures, a liquid phase containing $15-20$ at.\% $\mathrm{Si}$ dissolved in Ti forms. Qualitative analysis of the adhesion between the Ti metal and the glass showed the seal to be 'very poor'. For the $\mathrm{TiO}_{2}$ containing glass, adhesion was found to be dependent on the extent of reactions at the surface, i.e. the holding time. The seal with the La-doped glass was found to be 'fairly good' and attributed to the presence of very fine precipitates which gave a continuous structural transition from metal to glass. McColm and Dimbylow also investigated the wetting behaviour of sodium disilicate glass on Ti metal at $1000{ }^{\circ} \mathrm{C}$ [22]. They reported a sublimate of sodium and silicon in the furnace after the sealing. In addition, the underside of the glass bead after reaction was found to be black, in contrast to the 
Table 1 Some glass compositions investigated for general sealing and coating applications (mass\%)

\begin{tabular}{|c|c|c|c|c|c|c|c|c|c|c|c|c|c|}
\hline \multirow[t]{2}{*}{ Glass code } & \multicolumn{12}{|c|}{ Composition (mass\%) } & \multirow[t]{2}{*}{ Reference } \\
\hline & $\mathrm{Li}_{2} \mathrm{O}$ & $\mathrm{Na}_{2} \mathrm{O}$ & $\mathrm{K}_{2} \mathrm{O}$ & $\mathrm{MgO}$ & $\mathrm{CaO}$ & $\mathrm{BaO}$ & $\mathrm{ZnO}$ & $\mathrm{B}_{2} \mathrm{O}_{3}$ & $\mathrm{Al}_{2} \mathrm{O}_{3}$ & $\mathrm{SiO}_{2}$ & $\mathrm{P}_{2} \mathrm{O}_{5}$ & Others & \\
\hline \multicolumn{14}{|l|}{ Ti seals } \\
\hline Ti1 & - & $6-14$ & - & - & $22-26$ & - & - & - & $4-9$ & $50-58$ & - & - & [125] \\
\hline CABAL-12 & - & - & - & - & 15.9 & - & - & 43.8 & 28.9 & - & - & - & {$[28]$} \\
\hline CABAL-17 & - & - & - & - & 40.5 & - & - & 30.1 & 29.4 & - & - & - & {$[28]$} \\
\hline BABAL-1 & - & - & - & - & - & 43.9 & - & 26.6 & 9.7 & - & - & $19.8 \mathrm{SrO}$ & {$[28]$} \\
\hline 0080 & - & 17.0 & - & 4.0 & 5.0 & - & - & - & 1.0 & 73.0 & - & - & [28] \\
\hline TM-9 & - & 7.8 & 5.2 & - & - & 6.3 & - & - & 2.6 & 78.1 & - & - & {$[28]$} \\
\hline \multicolumn{14}{|l|}{ Ti coatings } \\
\hline Bioglass & - & 24.5 & - & - & 24.5 & - & - & - & - & 45.0 & 6.0 & - & [31] \\
\hline A3 & - & 12.0 & 4.0 & 8.5 & 15.0 & - & - & - & - & 54.5 & 6.0 & - & [31] \\
\hline $6 \mathrm{P} 44-\mathrm{a}$ & - & 23.6 & 6.5 & 7.1 & 12.6 & - & - & - & - & 44.2 & 6.0 & - & [33] \\
\hline $6 \mathrm{P} 50$ & - & 15.5 & 4.2 & 8.9 & 15.6 & - & - & - & - & 49.8 & 6.0 & - & [33] \\
\hline 6P61 & - & 10.3 & 2.8 & 7.2 & 12.6 & - & - & - & - & 61.1 & 6.0 & - & [33] \\
\hline $6 \mathrm{P} 68$ & - & 8.3 & 2.2 & 5.7 & 10.1 & - & - & - & - & 67.7 & 6.0 & - & [33] \\
\hline AWC & - & - & - & 1.92 & 48.2 & - & - & - & 1.9 & 33.3 & 13.3 & $0.03 \mathrm{CaF}_{2} ; 1.35$ 'others' & [143] \\
\hline $\mathrm{SCP}$ & - & 10.3 & 2.8 & 7.2 & 12.6 & - & - & - & - & 61.1 & 6.0 & - & {$[133]$} \\
\hline SAF & - & - & 10.5 & - & 19.6 & - & - & - & 17.9 & 26.2 & 17.5 & $8.3 \mathrm{~F}^{-}$ & [133] \\
\hline 2 & - & 16.9 & - & - & - & - & - & - & - & 58.3 & - & $24.8 \mathrm{TiO}_{2}$ & {$[21]$} \\
\hline \multicolumn{14}{|c|}{ Alternative seals and coatings } \\
\hline Basalt & - & 4.76 & 1.64 & 6.62 & 9.28 & - & - & - & 18.20 & 45.88 & 1.04 & $9.95 \mathrm{Fe}_{2} \mathrm{O}_{3} 2.63 \mathrm{LOI}$ & [124] \\
\hline Nimonic seal & - & - & - & 3.0 & 3.0 & 45.0 & 2.0 & - & - & 45.0 & - & $2.0 \mathrm{MoO}_{3}$ & [123] \\
\hline LSZH-03-1 & 8.88 & 5.42 & - & - & - & - & 7.77 & 5.00 & - & 69.98 & 2.95 & - & {$[170]$} \\
\hline LSZH-03-5 & 8.88 & 5.42 & - & - & - & - & 24.05 & 5.00 & - & 53.70 & 2.95 & - & {$[170]$} \\
\hline LZSL & 12.65 & - & 2.95 & - & - & - & 1.85 & 1.2 & 3.8 & 74.4 & 3.15 & - & {$[171]$} \\
\hline 7056 & 0.9 & 0.4 & 8.4 & - & - & - & - & 18.9 & 3.6 & 67.8 & - & - & {$[157]$} \\
\hline RC503 & 14.3 & - & 14.0 & - & - & - & - & 7.6 & - & 58.3 & 3.5 & $2.3 \mathrm{~V}_{2} \mathrm{O}_{5} ; 0.1 \mathrm{CoO}$ & {$[41]$} \\
\hline RC515 & 9.0 & - & 5.0 & - & - & - & 24.4 & 5.0 & - & 54.2 & 2.4 & - & [41] \\
\hline S-glass & 12.6 & - & 4.9 & - & - & - & - & 3.2 & 5.1 & 71.7 & 2.5 & - & [126] \\
\hline BPS-glass & 13.4 & - & 2.9 & - & - & - & 2.0 & 1.1 & 3.7 & 74.1 & 2.8 & - & [126] \\
\hline
\end{tabular}

clear glass before reaction. X-ray diffraction of the black layer indicated the presence of crystalline $\mathrm{TiO}_{2}, \mathrm{Ti}_{2} \mathrm{O}_{3}$ and $\mathrm{Ti}_{4} \mathrm{O}_{7}$ in the glass matrix. The adhesion of the glass to the titanium was found to be poor, with the contraction stresses on cooling sufficient to break the bond.

Using thermodynamic data on the free energy of reaction of $\mathrm{Ti}$ with a number of oxides, Sitnikova et al. [23] identified a number of oxides that should reduce the corrosion of $\mathrm{Ti}$ by molten glass. Experiments confirmed that the addition of $\mathrm{Li}_{2} \mathrm{O}, \mathrm{BeO}, \mathrm{CaO}, \mathrm{SrO}, \mathrm{BaO}$ and $\mathrm{CeO}_{2}$ did indeed limit corrosion. Similarly, substitution of oxides in the glass by less reactive oxides, for example, replacement of $\mathrm{Na}_{2} \mathrm{O}$ by $\mathrm{B}_{2} \mathrm{O}_{3}, \mathrm{MnO}$ or $\mathrm{ZnO}$, also minimized corrosion.

A comprehensive investigation of sealing between lithium silicate-based glass-ceramics containing $\mathrm{P}_{2} \mathrm{O}_{5}$ as a nucleating agent and $\mathrm{Ti}$ metal to form protective coatings was reported by Hong [24], Holland et al. [25], and Hong and Holland [26]. The glass-ceramic compositions involved small additions (typically less than 5 mass \%) of $\mathrm{Al}_{2} \mathrm{O}_{3}, \mathrm{~K}_{2} \mathrm{O}, \mathrm{ZnO}$ and $\mathrm{P}_{2} \mathrm{O}_{5}$. The exact compositions and thermal treatments were tailored to give a coefficient of thermal expansion close to that of Ti. Sealing of the glass to both clean and pre-oxidized titanium surfaces at temperatures up to $1000{ }^{\circ} \mathrm{C}$ for up to $40 \mathrm{~min}$ in an argon atmosphere was performed. In the case of the clean $\mathrm{Ti}$ surface, the presence of $\mathrm{Ti}_{5} \mathrm{Si}_{3}$ was observed, possibly via reaction (8), or alternatively by:

$5 \mathrm{Ti}_{(\text {metal })}+3 \mathrm{SiO}_{2 \text { (glass) }} \rightarrow \mathrm{Ti}_{5} \mathrm{Si}_{3 \text { (interface) }}+3 \mathrm{O}_{2} \uparrow$.

The evolution of gaseous oxygen resulted in a very porous coating. Further reactions involving the $\mathrm{P}_{2} \mathrm{O}_{5}$ nucleating agent and the evolution of oxygen were also noted to be favourable; for example: 
$16 \mathrm{Ti}+6 \mathrm{P}_{2} \mathrm{O}_{5} \rightarrow 4 \mathrm{Ti}_{4} \mathrm{P}_{3}+15 \mathrm{O}_{2} \uparrow$,

$9 \mathrm{Ti}+3 \mathrm{P}_{2} \mathrm{O}_{5} \rightarrow 2 \mathrm{Ti}_{4} \mathrm{P}_{3}+7 \mathrm{O}_{2} \uparrow+\mathrm{TiO}$,

$7 \mathrm{Ti}+6 \mathrm{P}_{2} \mathrm{O}_{5} \rightarrow 4 \mathrm{Ti}_{4} \mathrm{P}_{3}+14 \mathrm{O}_{2} \uparrow+\mathrm{TiO}_{2}$.

Reactions (9)-(12) were shown to be inhibited by $\mathrm{TiO}_{2}$ formed on pre-oxidation of the $\mathrm{Ti}$, and as a result, a wellfused coating was found to form; however, a relatively thick oxide coating was required to accomplish this, and cracks tended to occur at the interface between the $\mathrm{Ti}$ and $\mathrm{TiO}_{2}$ due to the low adherence between a thick oxide layer and the metal. Firing under air rather than Ar was found to reduce the evolution of oxygen by favouring reaction (8) over reaction (9); however, the seals were still found to be mechanically weak due to the continued presence of the brittle $\mathrm{Ti}_{5} \mathrm{Si}_{3}$ phase. Firing at a lower temperature of $900{ }^{\circ} \mathrm{C}$ did not produce a good seal due to rapid crystallization of the glass powder which inhibited sintering and prevented adequate wetting of the $\mathrm{Ti}$ surface. Hong and Holland [26] also investigated the use of a thin TiN layer on the surface of the metal, as a barrier between the glass and $\mathrm{Ti}$, by heating under nitrogen at 900-980 ${ }^{\circ} \mathrm{C}$. A porous microstructure was nevertheless again observed due to the reaction:

$$
\begin{aligned}
& 10 \mathrm{TiN}_{(\text {interface })}+6 \mathrm{SiO}_{2 \text { (glass) }} \rightarrow 2 \mathrm{Ti}_{5} \mathrm{Si}_{3 \text { (interface) }} \\
& \quad+6 \mathrm{O}_{2} \uparrow+5 \mathrm{~N}_{2} \uparrow .
\end{aligned}
$$

In the case of highly reactive metals, such as $\mathrm{Ti}$, the use of a traditional adherence promoting oxide can also make a very large difference to the quality of the seal [1]. An adherence promoting oxide has a lower energy of formation than $\mathrm{SiO}_{2}$, so that it reacts readily with $\mathrm{Ti}$ to give the required $\mathrm{TiO}_{2}$ at the interface. Use of $\mathrm{CoO}$, for example, leads to the following reaction:

$\mathrm{Ti}_{\text {(metal) }}+\mathrm{CoO}_{\text {(glass) }} \rightarrow 2 \mathrm{Co}_{\text {(precipitate) }}+\mathrm{TiO}_{2 \text { (glass) }}$.

Hong and Holland [26] reported that cobalt metallic particles and a $\mathrm{TiO}_{2}$-rich zone could be observed at the interface, and despite some $\mathrm{Ti}_{5} \mathrm{Si}_{3}$ still being detected, formed via reaction [8], especially after long firing times of up to $40 \mathrm{~min}$, the glass-ceramic layer was less porous and wetted the Ti well. The metallic Co precipitates in the glass-ceramic near the interface and improves the bond strength further by mechanical keying. The addition of other oxides into lithium silicate-based glasses has also been found to reduce the corrosion of $\mathrm{Ti}$ by the glass.

A calcium borosilicate glass with a coefficient of thermal expansion of $8.7 \times 10^{-6} / \mathrm{K}$, which closely matches that of $\mathrm{Ti}$, was reported by Donald et al. [27]. Coating of $\mathrm{Ti}$ by this glass was successful, but with scanning electron microscopy (SEM) showing some surface crystallization along the interface. A successful coating was also applied to $\mathrm{Ti}$ using the same glass doped with $\mathrm{Er}_{2} \mathrm{O}_{3}(9.6 \mathrm{~mol} \%$ ).
This glass has a slightly higher coefficient of thermal expansion, $9.6 \times 10^{-6} / \mathrm{K}$, but still provides a reasonable match to Ti. In this case, the glass partially crystallized, with the crystalline phase found to be rich in Er.

Brow and Watkins [28] prepared a number of seals to a commercial silicate sealing glass at $950{ }^{\circ} \mathrm{C}$ in an argon atmosphere. A thin reaction zone of approximately $1 \mu \mathrm{m}$ thickness was noted to form, thought to be $\mathrm{Ti}_{5} \mathrm{Si}_{3}$ formed via reaction (8). Despite the presence of the interfacial layer, the silicate seals were noted to be hermetic and exhibited reasonable mechanical properties. Analysis of the fractured seals showed no silicide phase on the glass sections and very little glass remained on the metal sections. This supports the previously suggested mechanism for the low strength of Ti to silicate glass seals which is via poor adhesion of the silicide to the glass. The quality of the seals compared to previous work on Ti-silicate seal systems was attributed to the relatively low-sealing temperature and short-sealing times employed.

\section{Boroaluminate-based glasses}

Brow and Watkins also reported a number of non-silicate, boroaluminate glasses for sealing to pure $\mathrm{Ti}$ and a $\alpha$-phase stabilized alloy of $\mathrm{Ti}$ [28]. Like the standard silicate-based bonding glasses, these glasses also have the required coefficient of thermal expansion, but the more highly reactive constituents are absent, suggesting that highquality hermetic seals to $\mathrm{Ti}$ should be achievable. The glasses also contained an alkaline earth oxide, either $\mathrm{CaO}$ (CABAL glasses), $\mathrm{SrO}$ (SRBAL glasses) or $\mathrm{BaO}$ (BABAL glasses). Sealing temperatures between 670 and $745^{\circ} \mathrm{C}$ for 10 min under argon were used, and high-quality hermetic seals were obtained with no interfacial reaction products detected by SEM in the sectioned seals; however, the presence of $\mathrm{Ti}$ was detected in the glass $\sim 15 \mu \mathrm{m}$ from the interface, and XPS also indicated the possibility of a mixed $\mathrm{TiB}_{2} / \mathrm{TiO}_{2}$ phase in the interfacial region. This phase was suggested to form through the following reaction:

$$
\begin{aligned}
& 5 \mathrm{Ti}_{\text {(metal) }}+2 \mathrm{~B}_{2} \mathrm{O}_{3 \text { (glass) }} \rightarrow 2 \mathrm{TiB}_{2 \text { (interface) }} \\
& \quad+3 \mathrm{TiO}_{2 \text { (interface) }} .
\end{aligned}
$$

Unlike many of the alternative studies on bonding to $\mathrm{Ti}$, the mechanical properties of the seals were tested by measuring the load required to fracture a simple seal configuration. The boroaluminate seals were found to be far superior to silicate seals, with approximately a 50\% greater load required to fracture the seal over an equivalent silicate seal. The stronger adhesion of the boroaluminate glasses was speculated to be due to two effects. Firstly, the interfacial boride phase bonds more strongly to the glass than the interfacial silicide phase; and secondly, a thinner 
interfacial reaction zone is formed with the boroaluminate glass due to its lower reactivity, and this minimizes the effects of any potential coefficient of thermal expansion mismatch with the interfacial products.

\section{Alkaline earth lanthanum borate glasses}

A number of alkaline earth lanthanum borate glasses were also developed by Brow for sealing to $\mathrm{Ti}$ and $\mathrm{Ti}$ alloys [29]. The coefficient of thermal expansion for the glasses was reported to be in the range $8.7-10.3 \times 10^{-6} / \mathrm{K}$. Sealing to metals was carried out at $700-800{ }^{\circ} \mathrm{C}$, which was about $150-200{ }^{\circ} \mathrm{C}$ above $T_{\mathrm{g}}$ for the glasses, under a nitrogen atmosphere. The product was a cylinder seal comprising a $\mathrm{Ti}$ or $\mathrm{Ti}$ alloy outer housing with a central pin of $\mathrm{Mo}, \mathrm{Pt}$ or $\mathrm{Ni}-48 \mathrm{Fe}$ alloy. The helium leak rates of the seals were tested and reported to be $<10^{-9} \mathrm{~cm}^{3} / \mathrm{s}$.

\section{Coatings on Ti for biomedical applications}

There are many studies prior to 2000 aimed at providing biocompatible coatings on Ti for implant applications. For example, a number of silicate-based glass coatings on $\mathrm{Ti}$ and Ti6Al4V alloy have been prepared by Bloyer et al. and Pazo et al. [30-32]. The compositions of the glasses are given in Table 1 . Coatings of thickness $25-150 \mu \mathrm{m}$ were prepared on the metal and alloy at temperatures between 700 and $1000{ }^{\circ} \mathrm{C}$. The quality of the glass-to-metal seal was found to have a very high dependence on the firing protocol of the sealing step, with high-quality, adherent coatings obtained with firings at $800-850{ }^{\circ} \mathrm{C}$ for $<60 \mathrm{~s}$. The addition of $\mathrm{TiO}_{2}$ broadens the range of times and temperatures that result in a high-quality seal. It proved impossible to achieve a good coating using Bioglass ${ }^{\circledR}$ due to fast crystallization of the glass. No significant differences between the coatings on the Ti metal and Ti6Al4V alloy were reported. It was concluded that for a highquality coating, a very thin interfacial layer is required, and this can be achieved by strict control of the reaction conditions. Similar experiments were performed using an argon atmosphere during the sealing step [31]. The result was no adhesion due to severe interfacial reactions between the metal and glass. This highlights the fact that a $\mathrm{TiO}_{x}$ oxide layer is critical to control reactivity and produce good adhesion between the metal and glass. Gomez-Vega et al., Saiz et al. and Lopez-Esteban et al. [33-35] prepared a large number of different glass compositions, see Table 1, for sealing to Ti6Al4V alloy. The application of a thin film of mesoporous silica by spin coating with a solgel solution was also investigated [36]. The coatings were fired between 700 and $860{ }^{\circ} \mathrm{C}$ in air and between 650 and $850{ }^{\circ} \mathrm{C}$ in nitrogen. These temperatures were noted as being close to the recommended annealing temperature for
Ti6Al4V alloy [37]. No appreciable grain growth was observed during the firings, which agrees with previously published grain growth kinetics for the alloy [38]. Highquality coatings were achieved using the glasses containing 56 mass $\%$ or more of $\mathrm{SiO}_{2}$. The optimum firing temperatures were found to be between 800 and $840{ }^{\circ} \mathrm{C}$, with a higher temperature required for higher $\mathrm{SiO}_{2}$ contents. Firing times were up to $1 \mathrm{~min}$ in air and $15 \mathrm{~min}$ in nitrogen.

Additional work has been reported using glass compositions with greater than 55 mass $\% \mathrm{SiO}_{2}$. A coating of the glasses 6 P57 or 6 P68 with Bioglass ${ }^{\circledR}$ or hydroxyapatiteembedded particles were used to coat a Ti6Al4V alloy by firing at $800{ }^{\circ} \mathrm{C}$ for $30 \mathrm{~s}$ [39]. A qualitative study of the adhesion was performed using Vickers indentation in air, indentation cracks regularly being used to study the adhesion of coatings $[1,40]$. For these coatings, the cracks never propagated along the interface, but were driven into the glass or across the particles. This confirms strong adhesion between the glass and alloy substrate.

Alternative metals and alloys

There are many other early studies covering the bonding of glasses or glass-ceramics to a wide variety of metals and alloys. These include $\mathrm{Pt}, \mathrm{Cu}, \mathrm{Ag}, \mathrm{Au}, \mathrm{Cr}, \mathrm{Mo}, \mathrm{W}, \mathrm{Al}, \mathrm{Ta}$, $\mathrm{Zn}$ and $\mathrm{Nb}$, together with alternative $\mathrm{Fe}$ - and Ni-based alloys, as reported elsewhere [1]. Additional studies include some early work on bonding glasses to Pd-based alloys [41]. In this study, the alloys Paliney 7 (35Pd-30Ag$14 \mathrm{Cu}-10 \mathrm{Au}-10 \mathrm{Pt}-1 \mathrm{Zn}$ ) and Paliney $\mathrm{M}$ were successfully sealed to alkali zinc silicate glasses.

\section{More recent studies with relevance to specific seal applications}

\section{SOFC alloys}

Unlike earlier fuel cell designs, solid oxide fuel cells, SOFC, are constructed entirely of solid materials. Solid oxide fuel cells convert chemical energy into electrical energy using hydrogen or a hydrocarbon-based fuel at elevated temperatures in the range $650-1000{ }^{\circ} \mathrm{C}$, but without the need for combustion. The process involves electrochemical oxidation of the fuel in preference to combustive oxidation. This results in higher efficiency and cleaner operation compared to conventional combustion processes and, in this era of high-energy requirements and environmental concerns, this makes them a more environmentally friendly option than, for example, conventionally driven steam turbines or diesel generators. During operation, a fuel and an oxidizing gas are combined via an ion-conducting electrolyte. If hydrogen is used as the fuel 
and air as the oxidizer, the only waste product is water. Currently, there are two basic SOFC designs: tubular [42, 43] and planar. The planar design is generally considered better than the tubular design, with advantages including higher operating power and simpler construction. To achieve high-power densities, the tubular design requires the bundling together of individual units, whilst the planar design requires the stacking of cells into a planar arrangement. A disadvantage of the planar design compared to the tubular design is that it requires high-temperature gas seals to join the cells together to form the stack. Schematic illustrations of a planar SOFC showing the positioning of the seals are shown in Fig. 5. An individual cell consists of the anode that may be cubic zirconia or a Ni/cubic zirconia cermet, an electrolyte of yttria-stabilized zirconia, Sr- and Mg-substituted lanthanum gallate, or Gd-substituted $\mathrm{CeO}_{2}$, and a cathode that may be lanthanum manganate, $\mathrm{LaMnO}_{3}$, or a mixed $\mathrm{LaSrCoFe}$-based oxide. Cells are joined together via an interconnect which may be a ferritic stainless steel or, for higher operating temperatures, a doped lanthanum chromite ceramic. The interconnect carries the current between the individual cells and acts as a separator between the oxidant and fuel. Individual cells are generally bonded to the next cell via a

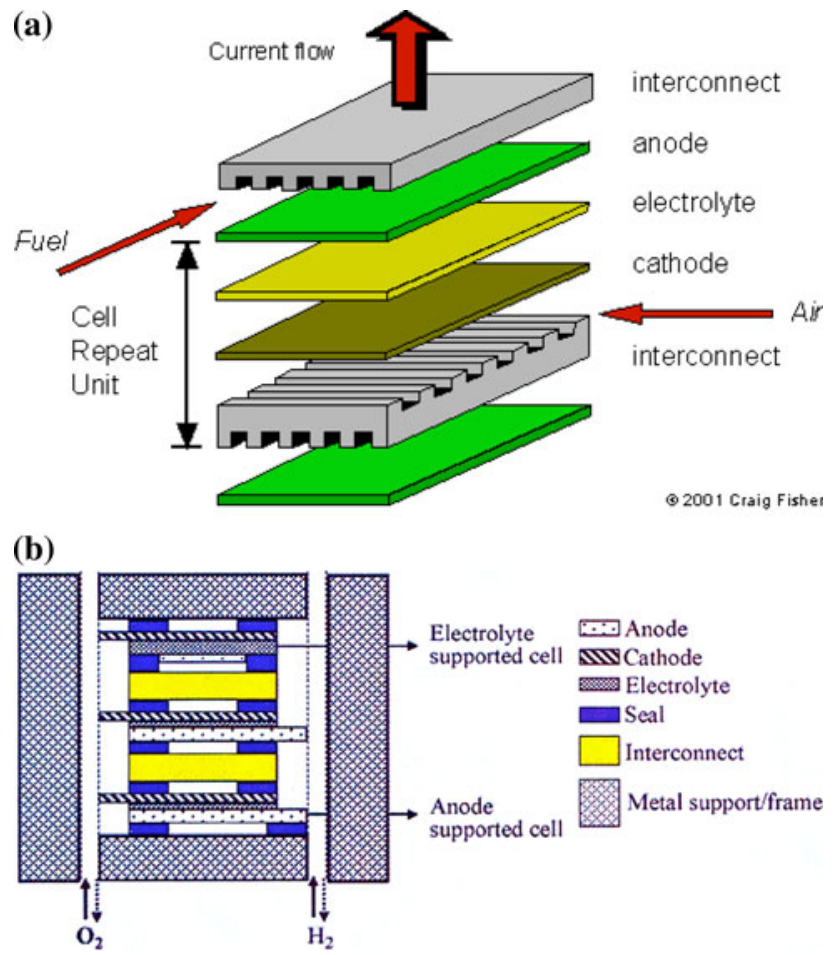

Fig. 5 Schematic illustrations of planar SOFC construction. a Exploded view. After www.spice.or.fisher/sofc. b Showing positioning of seals. Reprinted from Mahapatra and Lu [45], with permission from Elsevier glass or glass-ceramic seal, although other media have been attempted including mica and ceramic fibre composites [44, 45]. Brazing has also been employed for sealing SOFC components [46]. The whole unit is contained in a heat-resisting metal alloy housing, which may be stainless steel or a Ni-based superalloy. An experimental fuel cell stack is shown in Fig. 6. A variant on the SOFC is the solid oxide electrolyzer cell that is used to generate oxygen and hydrogen from steam and is likely to be an integral part of many of the proposed Generation IV nuclear energy systems.

Substantial work is in progress in the area of planar SOFCs, and there have been many recent reports on the development of glass- and glass-ceramic-to-metal seals for SOFC applications. Reviews by Steele and Heinzel [47], Fergus [48], Reis and Brow [49], Lessing [50], Singh [51], Kilner et al. [52] and Mahapatra and Lu [45] cover some of the work, with the emphasis on glass compositions. Other SOFC components have recently been reviewed by Singh and Minh [53], Weil et al. [54], Weil [55], Steinberger-Wilckens et al. [56], Lessing [50], Tucker [57] and Menzler et al. [58]. Fergus highlights the stringent requirements for such seals which, during fuel cell operation, and as noted above, are subjected to high temperatures, together with aggressive environments that are both oxidizing and reducing in nature, in addition to thermal cycling stresses [48]. Glasses and particularly glass-ceramics are ideal sealant candidates as their properties including thermal expansion can be

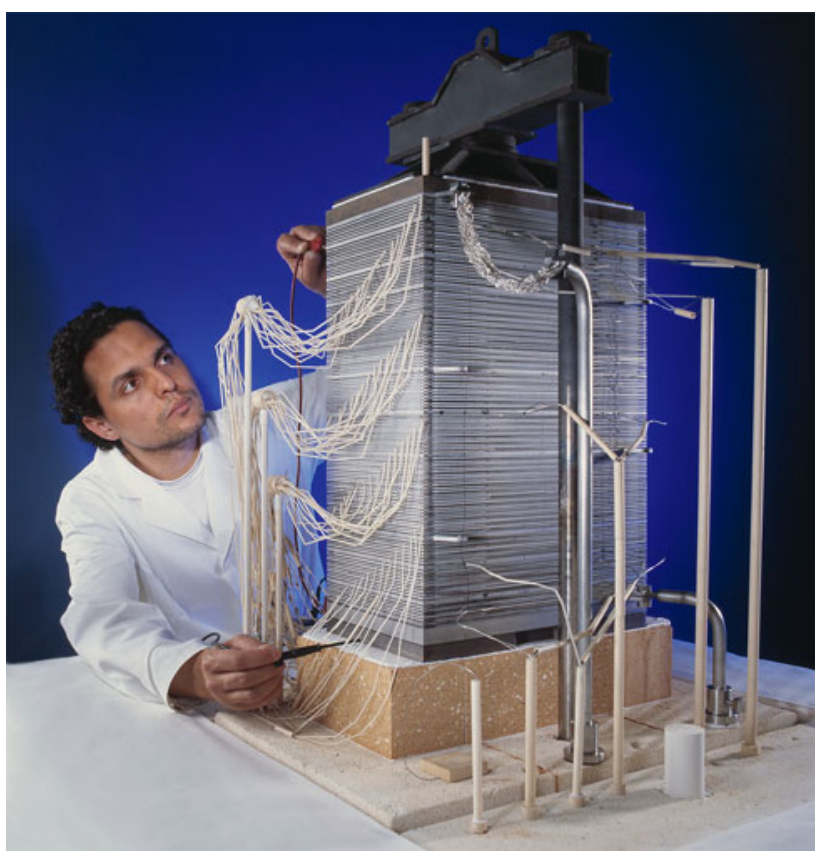

Fig. 6 SOFCs. Experimental unit. Julich Research Centre $13.3 \mathrm{~kW}$ 
tailored to be compatible with the other fuel cell materials. Glass-ceramics offer the additional advantage of higher operating temperatures. Some compositions of glasses employed as sealants in SOFC are summarized in Table 2, and selected properties are provided in Table 3 .

Table 2 Some glass compositions investigated for SOFC sealants (mass\%)

\begin{tabular}{|c|c|c|c|c|c|c|c|c|c|c|c|c|c|c|}
\hline \multirow[t]{2}{*}{ Glass code } & \multicolumn{13}{|c|}{ Composition (mass\%) } & \multirow[t]{2}{*}{ Reference } \\
\hline & $\mathrm{Na}_{2} \mathrm{O}$ & $\mathrm{MgO}$ & $\mathrm{CaO}$ & $\mathrm{BaO}$ & $\mathrm{SrO}$ & $\mathrm{Cr}_{2} \mathrm{O}_{3}$ & $\mathrm{ZnO}$ & $\mathrm{B}_{2} \mathrm{O}_{3}$ & $\mathrm{Al}_{2} \mathrm{O}_{3}$ & $\mathrm{SiO}_{2}$ & $\mathrm{Y}_{2} \mathrm{O}_{3}$ & $\mathrm{La}_{2} \mathrm{O}_{3}$ & Others & \\
\hline \multicolumn{15}{|l|}{ Alkaline earth silicate } \\
\hline BCAS4 & - & - & 9.2 & 55.6 & - & - & - & - & 5.5 & 25.3 & - & - & - & {$[67]$} \\
\hline BCAS5 & - & - & 8.8 & 57.4 & - & - & - & - & 5.4 & 22.1 & - & - & - & {$[67]$} \\
\hline $7 \mathrm{~A}$ & - & 16.90 & 18.82 & 6.43 & - & - & - & - & 2.14 & 47.88 & - & 6.83 & $1.0 \mathrm{NiO}$ & {$[66]$} \\
\hline $7(\mathrm{Sr})-2 \mathrm{~B}$ & - & 16.92 & 18.83 & - & 4.35 & - & - & 2.0 & 2.14 & 47.92 & - & 6.84 & $1.0 \mathrm{NiO}$ & {$[70]$} \\
\hline 7A-Cr & - & 16.82 & 18.72 & 6.40 & - & 0.5 & - & - & 2.13 & 47.64 & - & 6.80 & - & {$[66]$} \\
\hline $10 \mathrm{~B}$ & - & 16.48 & 18.34 & 6.27 & - & 0.5 & - & 2.00 & 2.08 & 46.67 & - & 6.66 & - & [74] \\
\hline $10 \mathrm{C}$ & - & 16.14 & 16.85 & 9.21 & - & 0.5 & - & 2.00 & 2.04 & 45.73 & - & 6.53 & - & [74] \\
\hline G-18 & - & - & 8.8 & 56.4 & - & - & - & 7.3 & 5.4 & 22.1 & - & - & - & {$[68,83,99,110]$} \\
\hline YSO-4 & - & - & 3.7 & - & 42.2 & - & 2.7 & 9.3 & - & 27.2 & 14.9 & - & - & [87] \\
\hline Glass \#27 & - & - & 15.0 & - & 26.6 & - & 15.0 & 1.9 & 4.1 & 35.2 & - & - & $2.2 \mathrm{TiO}_{2}$ & {$[65]$} \\
\hline Mg1.5-55 & - & 8.9 & - & 50.7 & - & - & - & - & - & 40.4 & - & - & - & {$[62]$} \\
\hline $\mathrm{Mg} 1.5-40-5 \mathrm{~B}-10 \mathrm{~Pb}$ & - & 7.4 & - & 42.0 & - & - & - & 3.5 & - & 24.4 & - & - & $22.7 \mathrm{PbO}$ & {$[62]$} \\
\hline $\operatorname{Mg} 1.5-40-15 B-8 Z n$ & - & 4.7 & - & 47.9 & - & - & 7.5 & 12.1 & - & 27.8 & - & - & - & {$[62]$} \\
\hline \multicolumn{15}{|c|}{ Alkali alkaline earth silicate } \\
\hline SACN & $9-12$ & - & $20-25$ & - & - & - & - & - & $10-14$ & $50-55$ & - & - & - & {$[77,81]$} \\
\hline SACNZn & 1.2 & 0.27 & 31.6 & - & - & - & 9.1 & - & 19.4 & 38.4 & - & - & - & {$[82]$} \\
\hline \multicolumn{15}{|c|}{ Alkaline earth borosilicate } \\
\hline $\mathrm{L} 2$ & - & - & - & 47.4 & - & - & - & 10.3 & 9.0 & 17.7 & - & 15.6 & - & [59] \\
\hline LO6 & - & - & - & 20.0 & - & - & - & 60.0 & 5.0 & 15.0 & - & - & - & [71] \\
\hline LO9 & - & - & - & 50.0 & - & - & - & 30.0 & 5.0 & 15.0 & - & - & - & [71] \\
\hline SrLaB & - & - & - & - & 15.2 & - & - & 20.5 & 9.0 & 3.5 & - & 51.8 & - & [91] \\
\hline MA12 & - & 8.4 & - & - & - & - & - & 8.8 & 9.7 & 22.7 & - & 50.4 & - & [72] \\
\hline VS1 & - & - & - & - & 33.9 & - & - & 15.2 & - & 26.2 & 24.7 & - & - & [79] \\
\hline VS2 & - & - & - & - & 29.8 & - & - & 13.4 & - & 23.0 & - & 33.8 & - & [79] \\
\hline VM1 & - & 16.6 & - & - & - & - & - & 19.2 & - & 33.1 & 31.1 & - & - & [79] \\
\hline VM3 & - & 20.1 & - & - & - & - & - & 23.1 & 16.9 & 39.9 & - & - & - & [79] \\
\hline BaBSi & - & - & - & 50.0 & - & - & - & 19.9 & - & 24.0 & 1.9 & 2.2 & $2.0 \mathrm{ZrO}_{2}$ & [108] \\
\hline 23 & - & - & 6.6 & 46.7 & - & - & - & 8.1 & 2.4 & 19.7 & - & 16.5 & - & {$[68]$} \\
\hline L09 & - & - & - & 68.6 & - & - & - & 18.7 & 4.6 & 8.1 & - & - & - & [71] \\
\hline P00 & - & - & - & 25.3 & - & - & - & 15.1 & 10.1 & 49.5 & - & - & - & [71] \\
\hline A2 & - & - & - & 60.6 & - & - & - & 12.6 & 5.0 & 21.8 & - & - & - & [73] \\
\hline VS1 & - & - & - & - & 33.9 & - & - & 15.2 & - & 26.2 & 24.7 & - & - & [79] \\
\hline 17 & - & 3.9 & 5.5 & 23.9 & - & - & - & 17.4 & 7.7 & 15.1 & - & 26.5 & - & [93] \\
\hline Glass \#59 & - & - & - & 34.3 & 23.2 & - & - & 15.6 & - & 26.9 & - & - & - & {$[65]$} \\
\hline A0 & - & - & - & 61.8 & - & - & - & 14.0 & - & 24.2 & - & - & - & [73] \\
\hline A2 & - & - & - & 60.6 & - & - & - & 12.6 & 5.0 & 21.8 & - & - & - & [73] \\
\hline \multicolumn{15}{|l|}{ Alkaline earth borate } \\
\hline $14 \mathrm{a}$ & - & 20.0 & 20.0 & 10.0 & - & - & - & 40.0 & 10.0 & - & - & - & - & [93] \\
\hline MA1 & - & 8.1 & - & - & - & - & - & 33.9 & 9.4 & - & - & 48.6 & - & {$[72]$} \\
\hline BM1 & - & 10.5 & - & 45.6 & - & - & - & 43.0 & - & - & - & - & - & {$[72]$} \\
\hline BMA1 (GC) & - & 6.0 & - & 6.7 & - & - & - & 32.2 & 8.9 & - & - & 46.2 & - & [72] \\
\hline BM2 (GC) & - & 9.7 & - & 50.1 & - & - & - & 40.2 & - & - & - & - & - & {$[72]$} \\
\hline
\end{tabular}




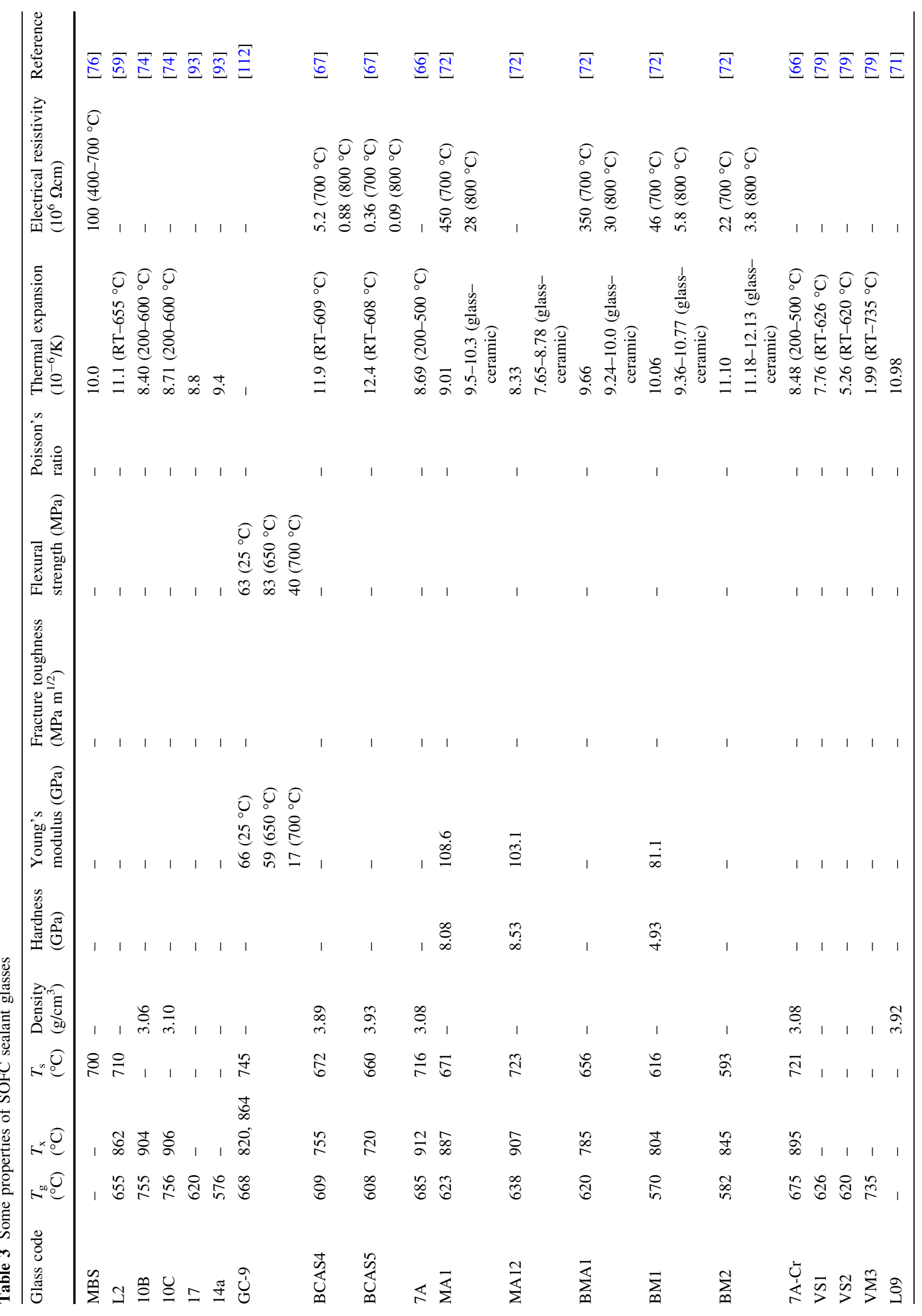




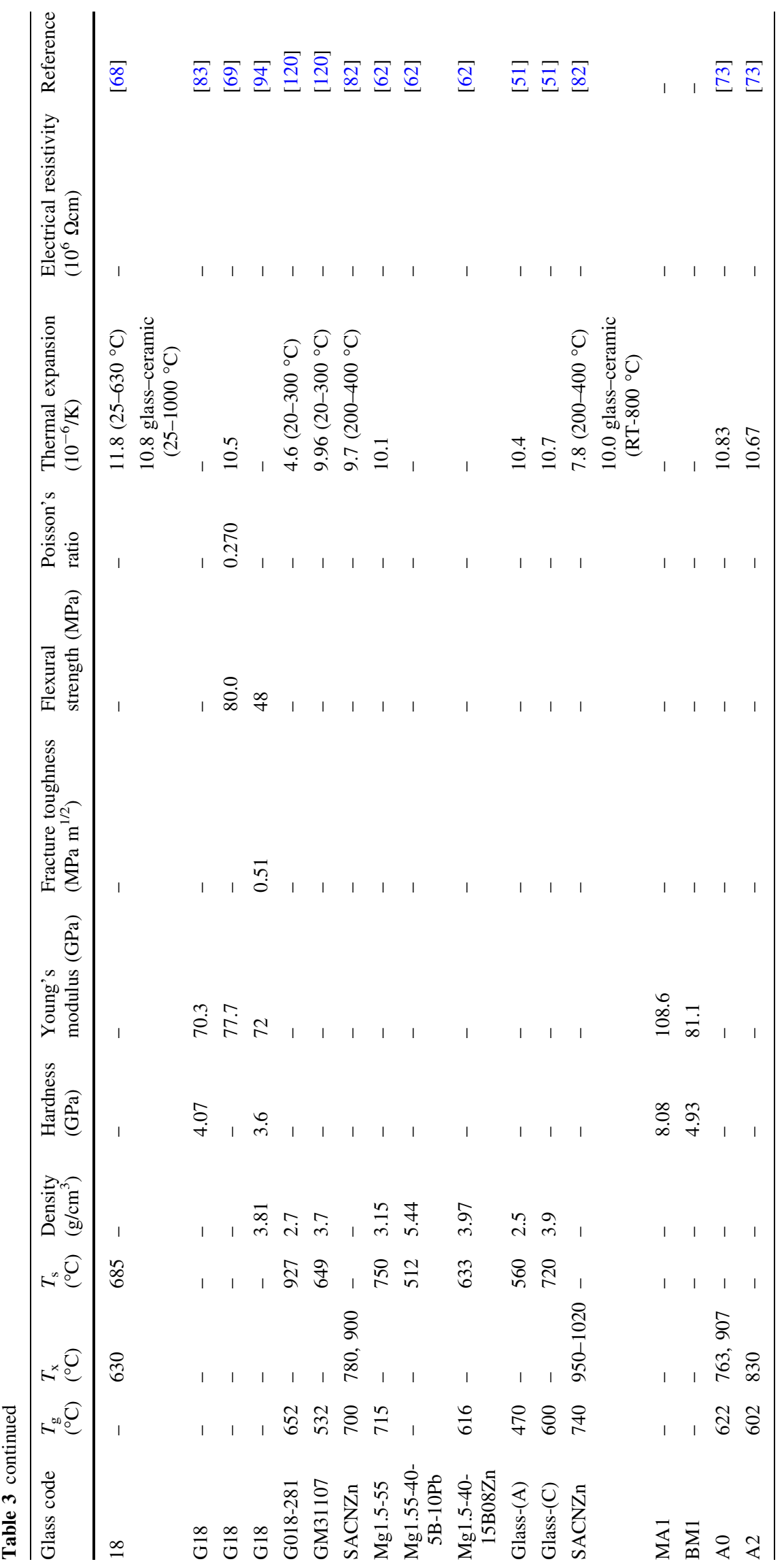


Metals commonly employed as interconnects in fuel cell designs include various austenitic and ferritic stainless steels, for example, $\mathrm{Fe} 20 \mathrm{Cr}$ and $\mathrm{FeCrAlY}$ alloys, in addition to Ni-based superalloys, as summarized in Table 4, whilst a range of glasses and glass-ceramics have been investigated as potential sealing media. These are mainly based on alkaline earth silicate compositions; for example, $\mathrm{BaO}-$ $\mathrm{Al}_{2} \mathrm{O}_{3}-\mathrm{SiO}_{2}$, often with additions of various oxides including $\mathrm{B}_{2} \mathrm{O}_{3}, \mathrm{CaO}, \mathrm{MgO}, \mathrm{SrO}, \mathrm{Na}_{2} \mathrm{O}, \mathrm{La}_{2} \mathrm{O}_{3}, \mathrm{Y}_{2} \mathrm{O}_{3}$, $\mathrm{TiO}_{2}, \mathrm{ZrO}_{2}, \mathrm{PbO}, \mathrm{V}_{2} \mathrm{O}_{5}, \mathrm{NiO}$ and $\mathrm{MnO}$ [59-74], together with some $\mathrm{BaO}$-free silicate glasses [74-89]. Low-silica and silica-free borate-based compositions have also been reported [90-93]. Some composite systems have also been investigated; for example, $\mathrm{MgO}$ particle reinforced glass [76], boron nitride nanotube reinforced glass [94], yttriastabilized zirconia nano- and micrometre-sized particle reinforced glass [95], sodium and sodium-free silicate particle reinforced glass [96], silver reinforced glass [97] and a novel glass composite containing a TiNiHf shape memory alloy mesh [98]. In general, interfacial reactions do not present serious problems during seal formation, although problems associated with thermal expansion mismatch between the metal and bulk glass-ceramic can occur, as shown, for example, in Fig. 7 [67]. Reactions do, however, become extremely critical during fuel cell operation, and cell ageing is therefore an extremely important aspect [83, 99-114]. Alkali-containing glass-ceramics are generally to be avoided due to the likelihood of pronounced glassceramic-metal reactions during cell operation. The alkaline

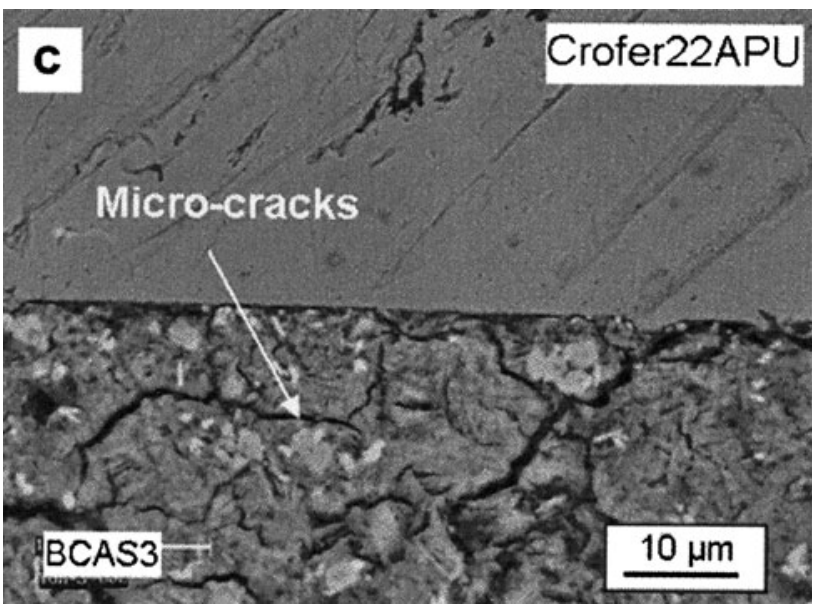

Fig. 7 Cracking in SOFC glass-ceramic seal due to thermal expansion mismatch. Reprinted from Ghosh et al. [67], with permission from Elsevier

earth aluminosilicate compositions are undoubtedly more stable, although interfacial reactions may occur to a greater or lesser extent; for example, reaction between the $\mathrm{BaO}$ containing glass-ceramics and stainless steel in the presence of oxygen to form $\mathrm{BaCrO}_{4}$ precipitates [99, 108], as shown in Fig. 8. Similar reactions are noted for $\mathrm{SrO}$ [106]: $2 \mathrm{Cr}_{2} \mathrm{O}_{3}+4(\mathrm{Ba} / \mathrm{Sr}) \mathrm{O}+3 \mathrm{O}_{2} \rightarrow 4(\mathrm{Ba} / \mathrm{Sr}) \mathrm{CrO}_{4}$.

In the case of $\mathrm{CaO}-\mathrm{BaO}-\mathrm{MgO}-\mathrm{Al}_{2} \mathrm{O}_{3}-\mathrm{SiO}_{2}$, glassceramics alternative reactions have been noted including

Table 4 Composition of metallic alloys

\begin{tabular}{|c|c|c|c|c|c|c|c|c|c|c|c|c|c|c|c|}
\hline \multirow[t]{2}{*}{ Alloy } & \multicolumn{15}{|c|}{ Element (mass\%) } \\
\hline & $\mathrm{Fe}$ & $\mathrm{Ni}$ & $\mathrm{Cr}$ & Co & $\mathrm{Ti} / \mathrm{Zr}$ & $\mathrm{Al}$ & $\mathrm{Nb} / \mathrm{Ta}$ & Mo & $\mathrm{Cu}$ & $\mathrm{Si}$ & $\mathrm{Mn}$ & $\mathrm{C}$ & $\mathrm{P}$ & Y/La & Others \\
\hline Crofer 22 & Balance & - & $20-24$ & - & $0.03-0.2$ & 0.12 & - & - & 0.5 & 0.5 & $0.3-0.8$ & 0.03 & 0.05 & $0.04-0.2$ & - \\
\hline JS-3 & Balance & - & 23.1 & - & 0.05 & $<0.01$ & - & - & - & $<0.01$ & 0.39 & 0.007 & - & 0.09 & - \\
\hline AISI446 & Balance & - & 25.0 & - & - & - & - & - & - & 1.0 & 1.50 & 0.20 & 0.04 & - & $\begin{array}{r}0.25 \mathrm{~N} \\
0.03 \mathrm{~S}\end{array}$ \\
\hline AISI441 & 80.68 & 0.20 & 17.6 & - & 0.18 & 0.045 & 0.46 & - & - & 0.47 & 0.33 & 0.01 & 0.024 & - & $0.001 \mathrm{~S}$ \\
\hline AISI1040 & Balance & - & 0.028 & - & - & - & - & 0.019 & - & 0.20 & 0.74 & 0.41 & 0.024 & - & $\begin{array}{c}0.032 \mathrm{~S} \\
0.001 \mathrm{~V}\end{array}$ \\
\hline Fecralloy & Balance & - & 22.0 & - & 0.1 & 5.0 & - & - & - & - & - & - & - & 0.1 & - \\
\hline $\begin{array}{l}\text { Nicrofer } \\
6025 \mathrm{HT}\end{array}$ & 9.5 & Balance & 25.0 & - & - & - & - & - & - & 0.5 & 0.10 & 0.2 & - & - & $2.1 \mathrm{~B}$ \\
\hline Ferritic T1 & Balance & 0.2 & 22.6 & - & 0.06 & 0.1 & - & - & - & 0.1 & 0.4 & - & - & 0.1 & - \\
\hline $\begin{array}{l}\text { Hastelloy- } \\
\text { XR }\end{array}$ & 17.8 & 49.5 & 22.0 & - & - & - & - & 8.7 & - & 0.33 & 0.88 & - & - & - & - \\
\hline $\begin{array}{r}\text { Nimonic } \\
\text { AE435 }\end{array}$ & 1.0 & Balance & $19-22$ & - & $0.15-0.35$ & 0.15 & - & - & 0.07 & 0.8 & 0.7 & 0.12 & 0.015 & - & $0.10 \mathrm{~S}$ \\
\hline E-brite & Balance & - & 26.5 & - & - & - & - & 1.0 & - & - & - & - & - & - & - \\
\hline $\begin{array}{l}\text { TIMETAL } \\
834\end{array}$ & - & - & - & - & $\begin{array}{l}3.5 \mathrm{Zr} \\
\text { Balance } \mathrm{Ti}\end{array}$ & 5.8 & 0.7 & 0.5 & - & 0.35 & - & 0.06 & - & - & $4 \mathrm{Sn}$ \\
\hline
\end{tabular}


Fig. 8 Reaction at seal edge between glass and metal to form $\mathrm{BaCrO}_{4}$ precipitates. Reprinted from Peng and Zhu [108], with permission from Elsevier

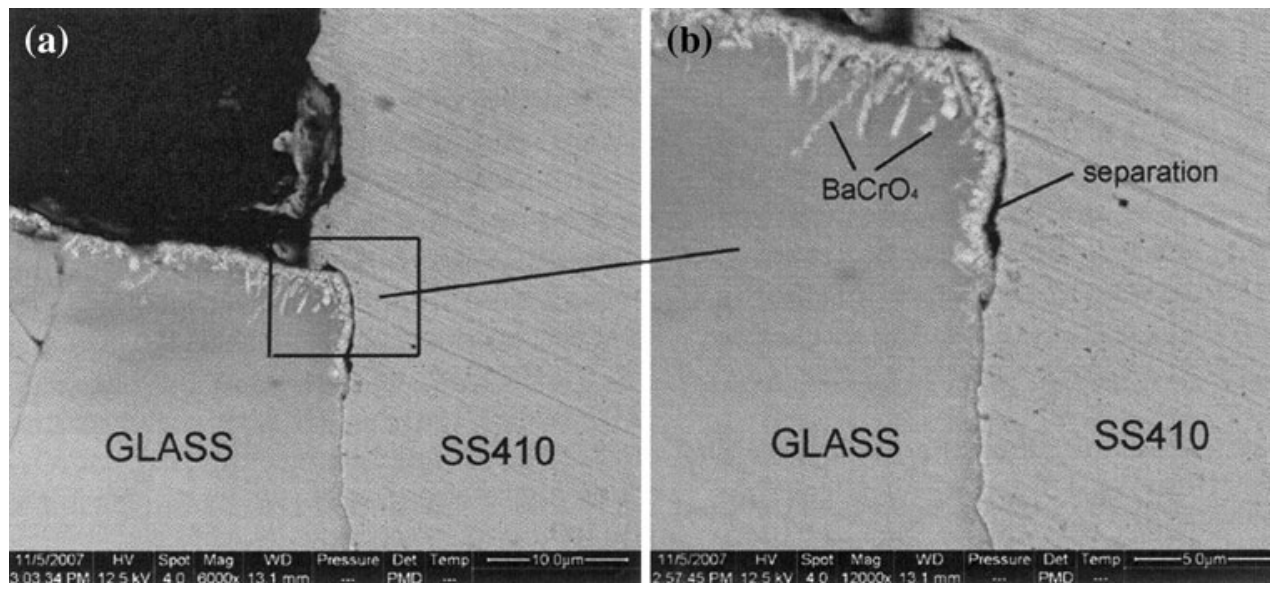

the formation of $\mathrm{MgCrO}_{4}$ and $\mathrm{Ca}_{3} \mathrm{Cr}_{2} \mathrm{Si}_{2} \mathrm{O}_{8}$ precipitates, as reviewed by Fergus [48], whilst for compositions which contain $\mathrm{ZnO}$ or $\mathrm{PbO}$ reduction to the metallic state, which will be liquid at the cell operating temperatures, has been observed [62, 103]. Diffusion of metal constituents into the glass or glass-ceramic through an interfacial zone is common as shown in Figs. 9, 10 and 11. In addition, as is now known from earlier work to be common for many glass- and glass-ceramic-to-metals seals, reaction of $\mathrm{Cr}$ or other reactive species with water present in the starting glass or the operating environment may produce bubbles within the seal interface $[1,99]$. In the case of glass sealants, partial crystallization during operation will lead to a change in thermal expansion characteristics or mechanical properties, which may be detrimental to cell operation [112]. A sealing glass may also undergo some surface crystallization, as is the case for SABS-0, a new boron-free $\mathrm{SrO}-\mathrm{La}_{2} \mathrm{O}_{3}-\mathrm{Al}_{2} \mathrm{O}_{3}-\mathrm{SiO}_{2}$ composition, and this may affect overall cell performance in the longer term. Studies by Jin and $\mathrm{Lu} \mathrm{[114]}$ on the stability of this glass indicated that in the form of bulk polished plates crystals of $\mathrm{Sr}_{2} \mathrm{SiO}_{4}$, $\mathrm{Al}_{2} \mathrm{SiO}_{5}$ and $\mathrm{Sr}_{7} \mathrm{Al}_{12} \mathrm{O}_{25}$ formed in the surface of the glass when heated in air, but the bulk of the glass remained amorphous.

Many other effects are observed during ageing of seals at temperature either in air or $\mathrm{H}_{2} / \mathrm{H}_{2} \mathrm{O}$ atmospheres, as discussed in the article by Jin and Lu [113, 114], with a comprehensive investigation of the compatibility between AISI441 stainless steel and four different sealing glasses reported. Glasses considered included a strontium borosilicate composition (YSO-4) with a glass transition temperature of $713{ }^{\circ} \mathrm{C}$ and thermal expansion $11.7 \times 10^{-6} / \mathrm{K}$; a barium-rich boroaluminosilicate glass (G18) with $T_{\mathrm{g}}$ of $630{ }^{\circ} \mathrm{C}$ and expansion $11.8 \times 10^{-6} / \mathrm{K}$, and which can be easily partially crystallized to give a glass-ceramic material with expansion $10.8 \times 10^{-6} / \mathrm{K}$; a barium- and boronfree strontium lanthanum aluminosilicate glass (SABS-0) with $T_{\mathrm{g}}$ of $755^{\circ} \mathrm{C}$; and a sodium calcium boroaluminosilicate glass (SCAN2) with $T_{\mathrm{g}}$ of $545^{\circ} \mathrm{C}$, which also partially crystallizes. In this study, seals were prepared between these glasses and the stainless steel, and subsequently subjected to extend ageing up to $500 \mathrm{~h}$ at $800{ }^{\circ} \mathrm{C}$ in air and an $\mathrm{H}_{2} / \mathrm{H}_{2} \mathrm{O}$ atmosphere. Microstructures of seals in as-bonded and aged condition are shown in Fig. 12. It is very clear that the SABS-0 glass provides the best option under all conditions. Seals with the YSO-4 glass crystallize during sealing to give a variety of phases including $\mathrm{SrCrO}_{4}$ by reaction with $\mathrm{Cr}$ diffusing from the metal. The G18 glass also reacts with $\mathrm{Cr}$ and $\mathrm{Fe}$ diffusing from the metal to form $\mathrm{BaCrO}_{4}$ and $\mathrm{BaFeSi}_{4} \mathrm{O}_{10}$, respectively. Reaction with diffusing $\mathrm{Fe}$ takes place in the case of the SCAN2 glass to give $\mathrm{Ca}_{3} \mathrm{Fe}_{2}\left(\mathrm{SiO}_{4}\right)_{3}$ and $\mathrm{CaFe}_{2} \mathrm{O}_{4}$ phases in the interfacial region. On the other hand, very little reaction occurs in the case of the SABS-0 glass, although some $\mathrm{La}_{2} \mathrm{CrO}_{6}$ precipitates are formed at the interface by reaction of $\mathrm{La}$ in the glass with diffusing $\mathrm{Cr}$. On ageing, this phase disappears and is replaced by a $\mathrm{Sr}_{7} \mathrm{Al}_{12} \mathrm{O}_{25}$ crystalline phase.

Cracking within the bulk glass may also occur due to differential thermal expansion between different phases, as shown in Fig. 13 [72]. Similarly, for glass-ceramics, a change in crystalline morphology and the formation of voids during operation, as shown in Fig. 14, may also affect the long-term properties [69]. Creep of the glassceramic during service may also lead to long-term cell degradation [83]. In the case of glass sealants, maximum operating temperatures will be limited by $T_{\mathrm{g}}$ of the glass. For glass-ceramics, on the other hand, higher operating temperatures will generally be possible, and it has also been suggested that self-healing may occur during thermal cycling, whereby cracks or voids generated during cooling may restore mechanical performance $[73,85,105,115-$ 117]. A novel seal design utilizing glass containing a NiTiHf shape memory alloy mesh has also been suggested as beneficial to self-healing [98]. Stresses resulting from 


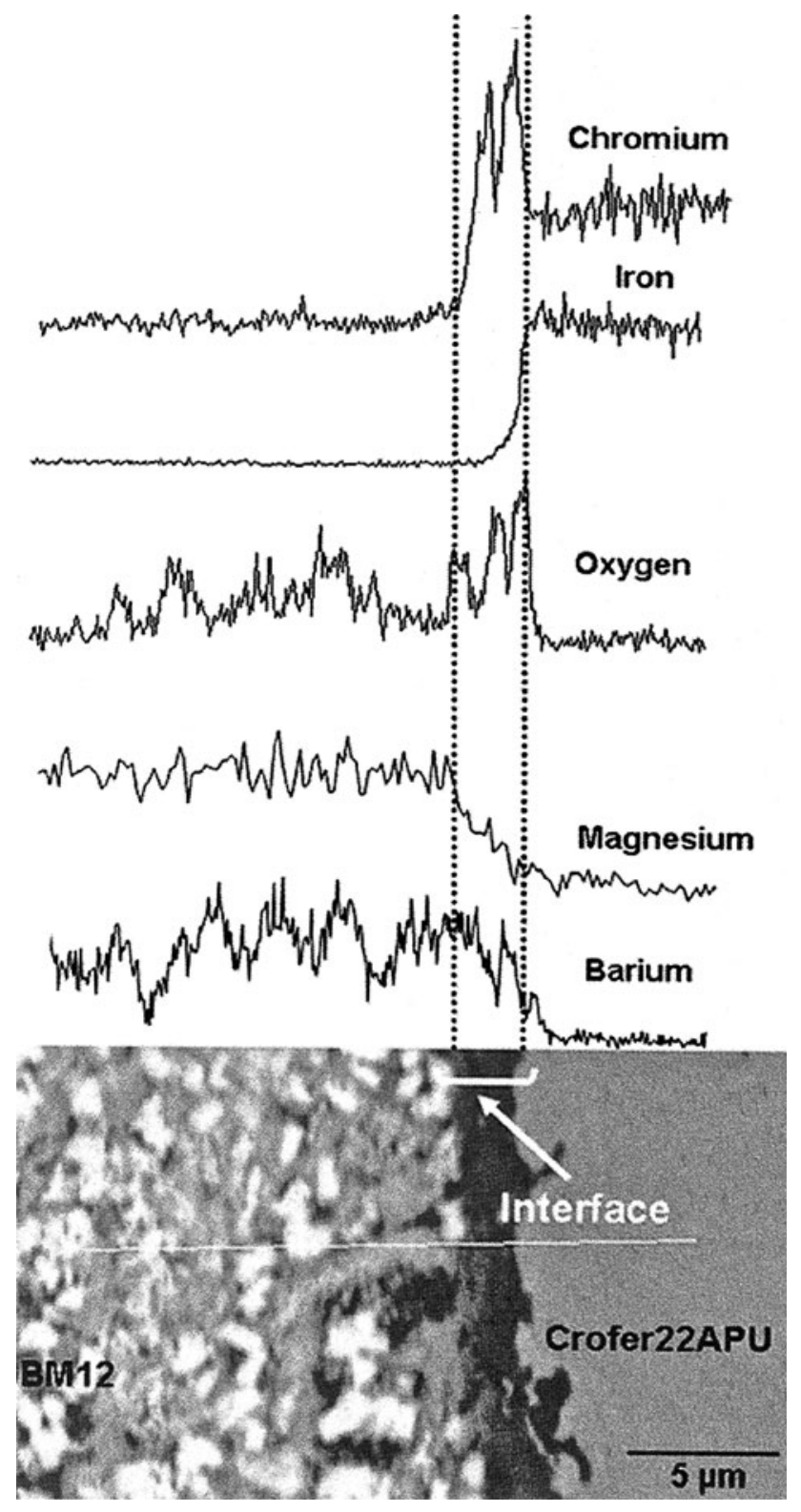

Fig. 9 Interface between Crofer22APU alloy and glass with line scans for $\mathrm{Cr}, \mathrm{Fe}, \mathrm{O}, \mathrm{Mg}$ and $\mathrm{Ba}$. Reprinted from Ghosh et al. [72], with permission from Int. J. Hydrogen Energy

thermal expansion changes of the glass due to crystallization under prolonged heating are subsequently relieved by transformation of the alloy from an austenitic to a martensitic structure. It has been noted, however, that when using SABS-0 with NiTiHf alloy, severe interfacial reactions may occur [117]. Reinforcement of glass with silver has also been found beneficial in promoting self-healing [97].

The majority of reactions that occur are detrimental to fuel cell operation and lifetime behaviour. Internal oxidation and grain boundary attack of the metal components themselves may also occur during operation and this can

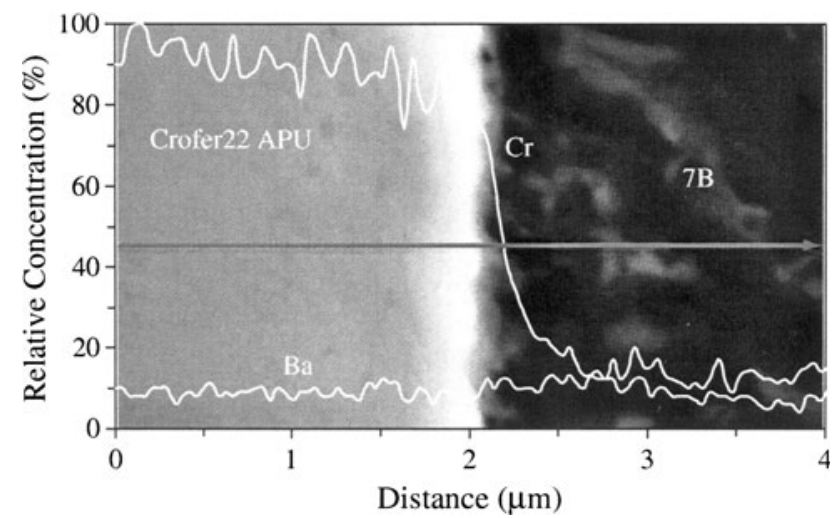

Fig. 10 Interface between Crofer22APU alloy and diopside glassceramic with line scans for $\mathrm{Cr}$ and $\mathrm{Ba}$. Reprinted from Goel et al. [66], with permission from Elsevier

cause swelling of the metal, leading to interface failure [103]. It is important that these reactions are avoided or minimized and it has been noted, for example, that unwanted interactions between stainless steel and glassceramics can be minimized by applying a thin plasmasprayed coating of zirconia to the steel prior to sealing [103]. Pre-oxidation of the metal components prior to sealing has also been found to be beneficial in minimizing diffusion of $\mathrm{Cr}$ and $\mathrm{Fe}$ into the glass-ceramic both during sealing and during cell operation [77, 78], as illustrated in Fig. 15.

The electrical resistance of the sealing glass or glassceramic is of course also of great importance [76, 87], in particular the way in which this may change with temperature. A plot of resistance against temperature for a glass sealant is shown in Fig. 16 [76]. In an attempt to prevent the build up of $\mathrm{Cr}$ onto the cathode material due to volatilization from the interconnect during cell operation, coatings of $(\mathrm{Mn}, \mathrm{Co})_{3} \mathrm{O}_{4}$ spinel have been applied to $\mathrm{Cr}$-containing interconnect alloys [118]. Although this is effective in stabilizing the electrical characteristics of the cell, unfortunately this coating is not normally fully compatible with the sealing glasses employed; however, recent work has shown that a second coating of alumina can alleviate this problem [119].

Commercial sealing glasses suitable for SOFC applications are available; for example, from Schott [120], and also from such companies as GE, Siemens and Kyocera.

\section{Other high-temperature seals}

Thermal barrier coatings are required to protect Ni-based superalloy components in advanced gas turbine and diesel engines which operate at higher temperatures and with reduced air cooling relative to conventional engine components [121-123]. Recently reported coatings for these applications include those based on magnesium and zinc 
Fig. 11 Interfaces between sealing glass, YSZ and Crofer22APU alloy. Reprinted from Smeacetto et al. [82], with permission from Elsevier
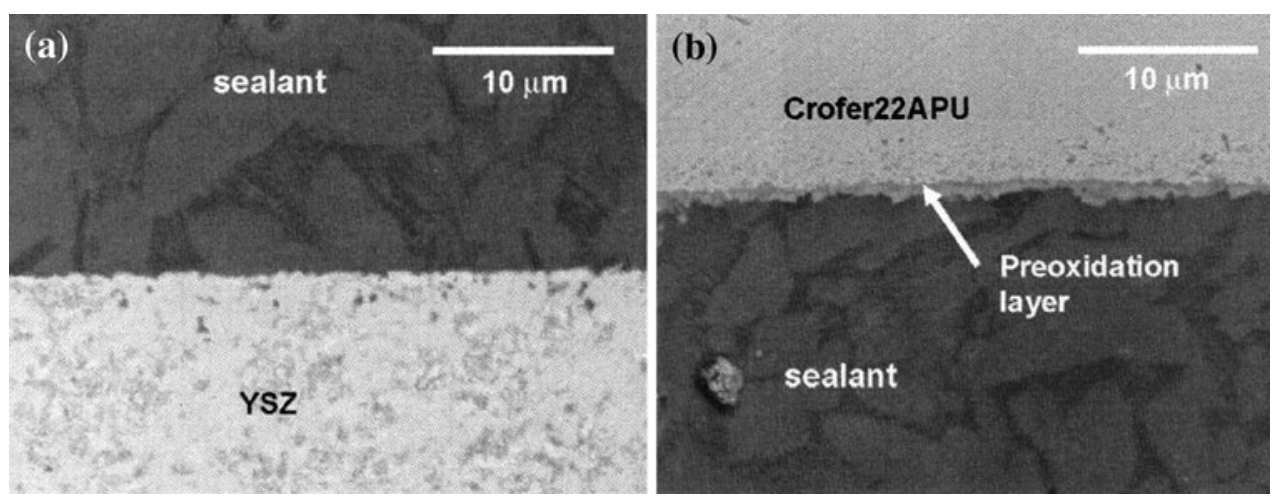

aluminosilicate glass-ceramics, together with hybrid alkaline earth zinc molybdenum silicate glass-ceramic/yttriastabilized zirconia composite coatings [121]. Additional coatings include basalt-based glass-ceramics prepared from waste materials including fly ash and which can be plasma sprayed onto steel substrates to provide wear and abrasion resistance or thermal protection [124]. Thermal barrier glass-ceramic coatings from the $\mathrm{Na}_{2} \mathrm{O}-\mathrm{CaO}-$ $\mathrm{Al}_{2} \mathrm{O}_{3}-\mathrm{SiO}_{2}$ system have also been successfully applied to Ti alloys with particularly good results, as shown in Fig. 17 [125]. Recent work on the sealing of thin slices of lithium silicate based S- and BPS-glasses to a variety of Ni-based superalloys for potential high-temperature applications has been reported by Bengisu et al. [126]. The alloys included Inconel 600 and 718, Haynes 230 and Hastelloy C-276. It was noted that the BPS glass, which contained 2 mass $\%$ $\mathrm{ZnO}$, bonded successfully to all the alloys, whilst the S-glass only sealed successfully to Inconel 600. The influence on seal integrity of heating in air in the range 700-900 ${ }^{\circ} \mathrm{C}$ for $100 \mathrm{~h}$ was subsequently monitored. It was noted that all the successful seals failed at $900{ }^{\circ} \mathrm{C}$, whilst all remained intact at $700{ }^{\circ} \mathrm{C}$. At $800{ }^{\circ} \mathrm{C}$, only the seals to Inconel 600 remained intact. It was concluded that the presence of $\mathrm{ZnO}$ in the starting glass improves the bonding characteristics by providing a thin Zn-rich interfacial layer that helps prevent excessive reaction at the interface. Overall, the BPS glass was considered suitable for sealing to the alloys in question for applications up to $800{ }^{\circ} \mathrm{C}$ in air. A double layered glass-ceramic applied to a Ti alloy for improved oxidation resistance at temperatures up to around $800{ }^{\circ} \mathrm{C}$ has also been reported recently [127]. A recent review of ceramics employed in heat exchangers also makes reference to glass sealants [128].

\section{Coatings on $\mathrm{Ti}$ for biomedical applications}

As noted earlier, there is a high-demand for metallic materials to be used in the medical industry as prosthetic implants due to their advantageous mechanical properties, and interest in coatings for these materials has increased over recent years. As a result of their high-strength, lowdensity and non-toxicity, the use of $\mathrm{Ti}$ and $\mathrm{Ti}$ alloys for prostheses has now become very wide spread. To improve the prostheses adhesion to bone and minimize corrosion of the metal a bioactive glass, glass-ceramic or hydroxyapatite, $\mathrm{Ca}_{10}\left(\mathrm{PO}_{4}\right)_{6}(\mathrm{OH})_{2}$, can be applied as a coating [129132]. Verné et al. prepared a double layer coating of a glass and glass-ceramic on Ti6Al4V alloy [133]. The alloy was first coated with glass 6P61, using a thermal treatment of $15 \mathrm{~s}$ at $840{ }^{\circ} \mathrm{C}$. The second coating consisted of a glassceramic with the composition (in mass\%) $26.2 \mathrm{SiO}_{2}, 17.9$ $\mathrm{Al}_{2} \mathrm{O}_{3}, 17.5 \mathrm{P}_{2} \mathrm{O}_{5}, 19.6 \mathrm{CaO}, 10.5 \mathrm{~K}_{2} \mathrm{O}$ and $8.3 \mathrm{~F}$ (added as $\mathrm{Na}_{3} \mathrm{AlF}_{6}$ and $\mathrm{K}_{3} \mathrm{AlF}_{6}$ ) designed to be more bioactive than the first layer glass. It was added using an additional thermal treatment at $950{ }^{\circ} \mathrm{C}$ for $30 \mathrm{~s}$. Analysis showed a high-degree of adhesion and absence of a detrimental reaction layer between the glass and the alloy even after the second higher temperature firing. Pavon and Pavon et al. have also used indentation techniques to study the adhesion between a glass and Ti6Al4V alloy [134-137]. Glass 6P64 was bonded to the alloy between 800 and $820^{\circ} \mathrm{C}$. The interfacial response to monotonic and cyclic Hertzian indentation was investigated and compared to the 6P61 glass. Microstructural analysis of the interfaces showed some porosity caused by the evolution of oxygen gas via reaction (9), the degree of porosity increasing as the firing time was increased. The glass with the lower $\mathrm{SiO}_{2}$ content was found to have a higher degree of residual stress due to the greater thermal expansion mismatch. Alternative methods for applying a glass or glass-ceramic coating have also been investigated. For example, Stojanovic et al. have used electrophoretic deposition (EPD) to coat Ti6Al4V alloy with a silicate-based glass [138]. EPD is a colloidal process wherein ceramic bodies or coatings are shaped directly from a stable colloid suspension by a dc electric field [139, 140]. Pulsed laser deposition has also been used to coat Ti substrates with silicate-based bioactive glasses [141].

Mixed leucite glass, hydroxyapatite and $\mathrm{CaF}_{2}$ glassceramic systems have been prepared by Kulinich et al. for 
Fig. 12 Interfaces between AISI441 stainless steel and various glasses before and after treatment at $800{ }^{\circ} \mathrm{C}$. (A) YSO-4 glass in air: (a) as-bonded, (b) $100 \mathrm{~h},(c) 200 \mathrm{~h},(d) 500 \mathrm{~h}$. (B) SABS-0 glass, $(a-d)$ as above. (C) YSO-4 glass in $\mathrm{H}_{2} / \mathrm{H}_{2} \mathrm{O}$ atmosphere: (a) $100 \mathrm{~h}$, (b) $200 \mathrm{~h}$, (c) $500 \mathrm{~h}$. (D) SABS0 glass in $\mathrm{H}_{2} / \mathrm{H}_{2} \mathrm{O}$ atmosphere, $(a-c)$ as above. Reprinted from Jin and Lu [114], with permission from Elsevier
(A)
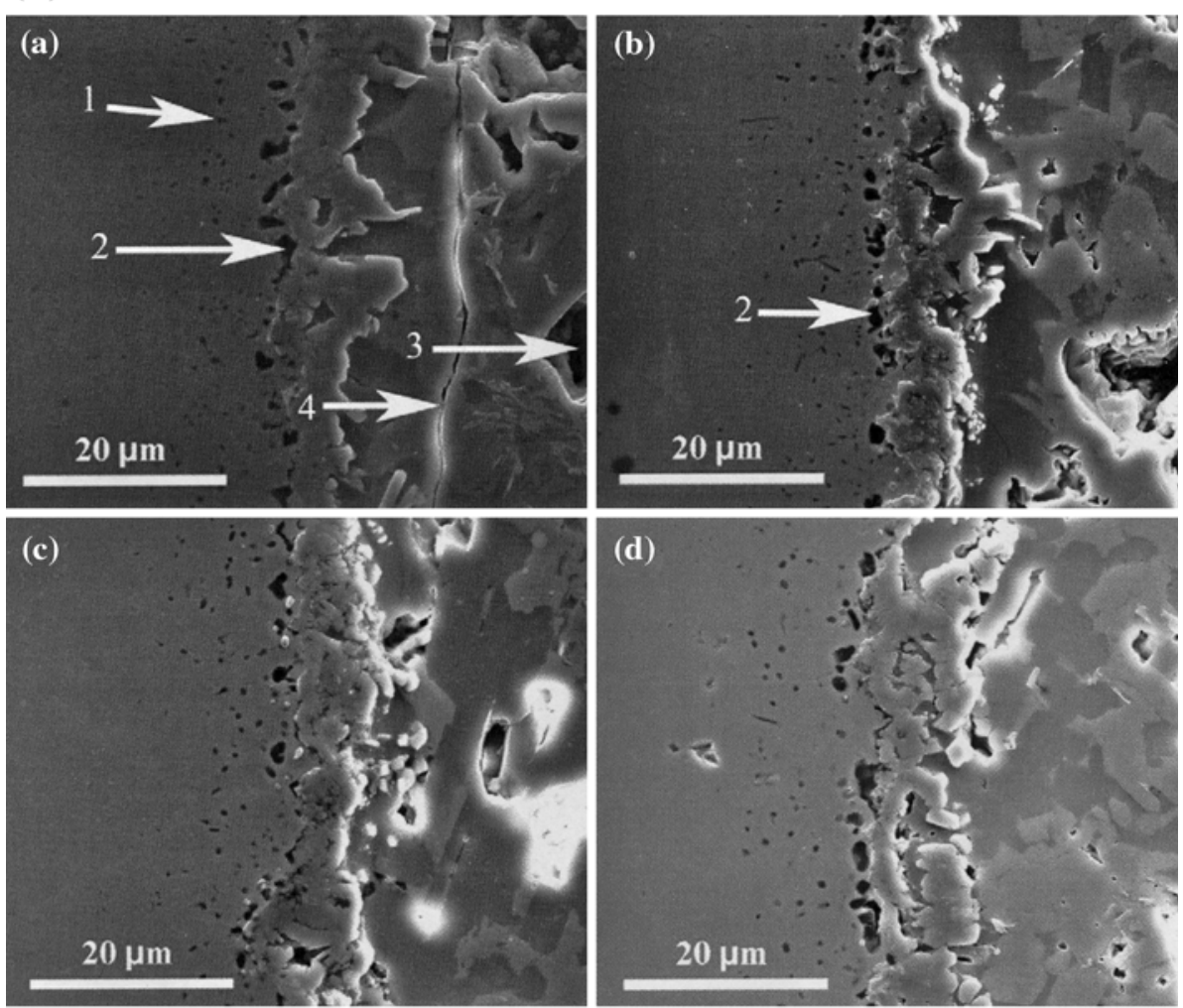

(B)
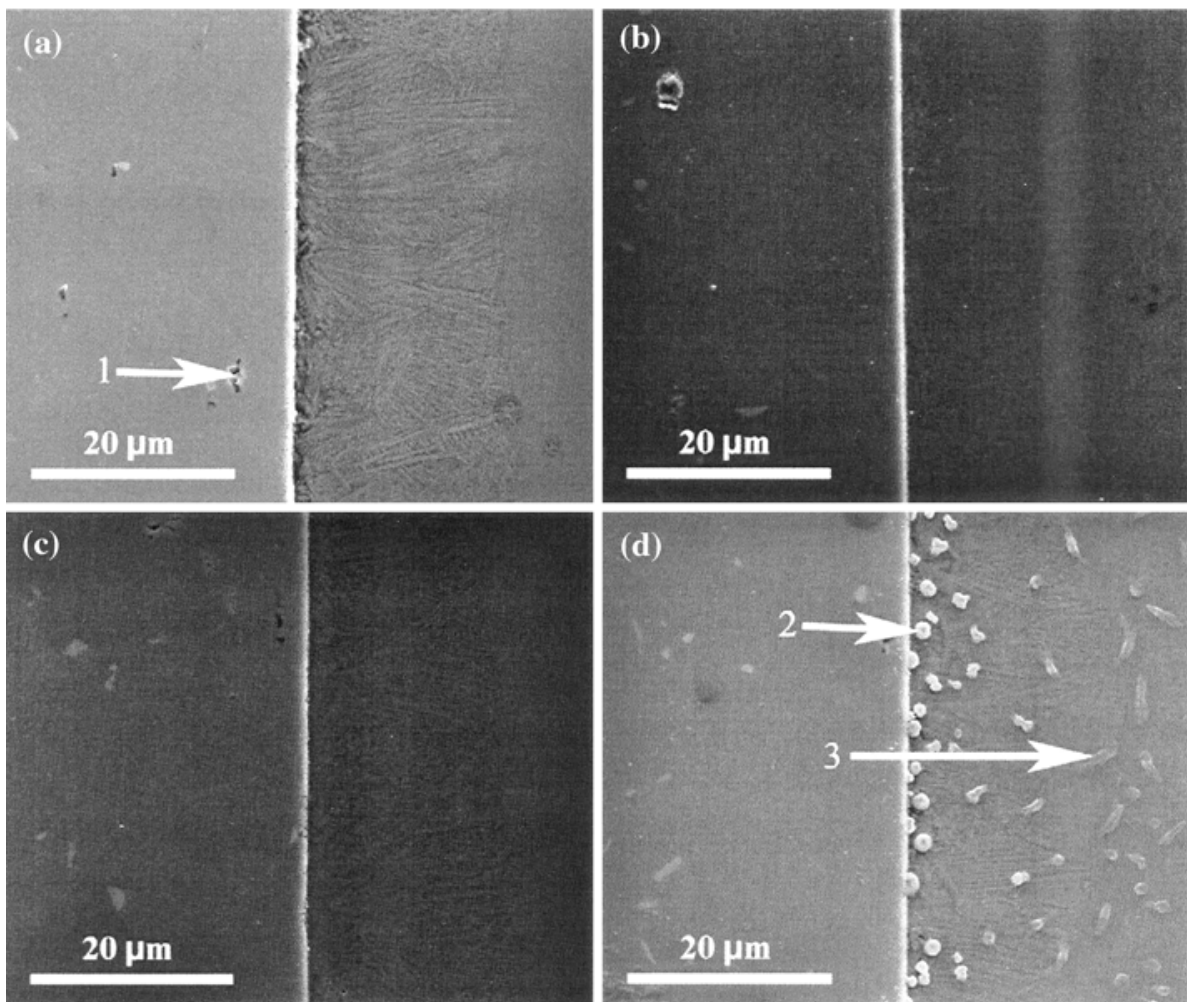

coating Ti [142]. The coatings were found to be low in porosity, with a uniform distribution of the crystalline and amorphous phases. Mixed apatite/wollastonite coatings have also been applied to Ti alloys by Cannillo et al. [143] and bioactive coatings to a $\mathrm{Ti}-\mathrm{Nb}-\mathrm{Ta}-\mathrm{Zr}$ alloy by $\mathrm{Li}$ et al. [144]. Bibby et al. reported successful application of 
Fig. 12 continued

(C)
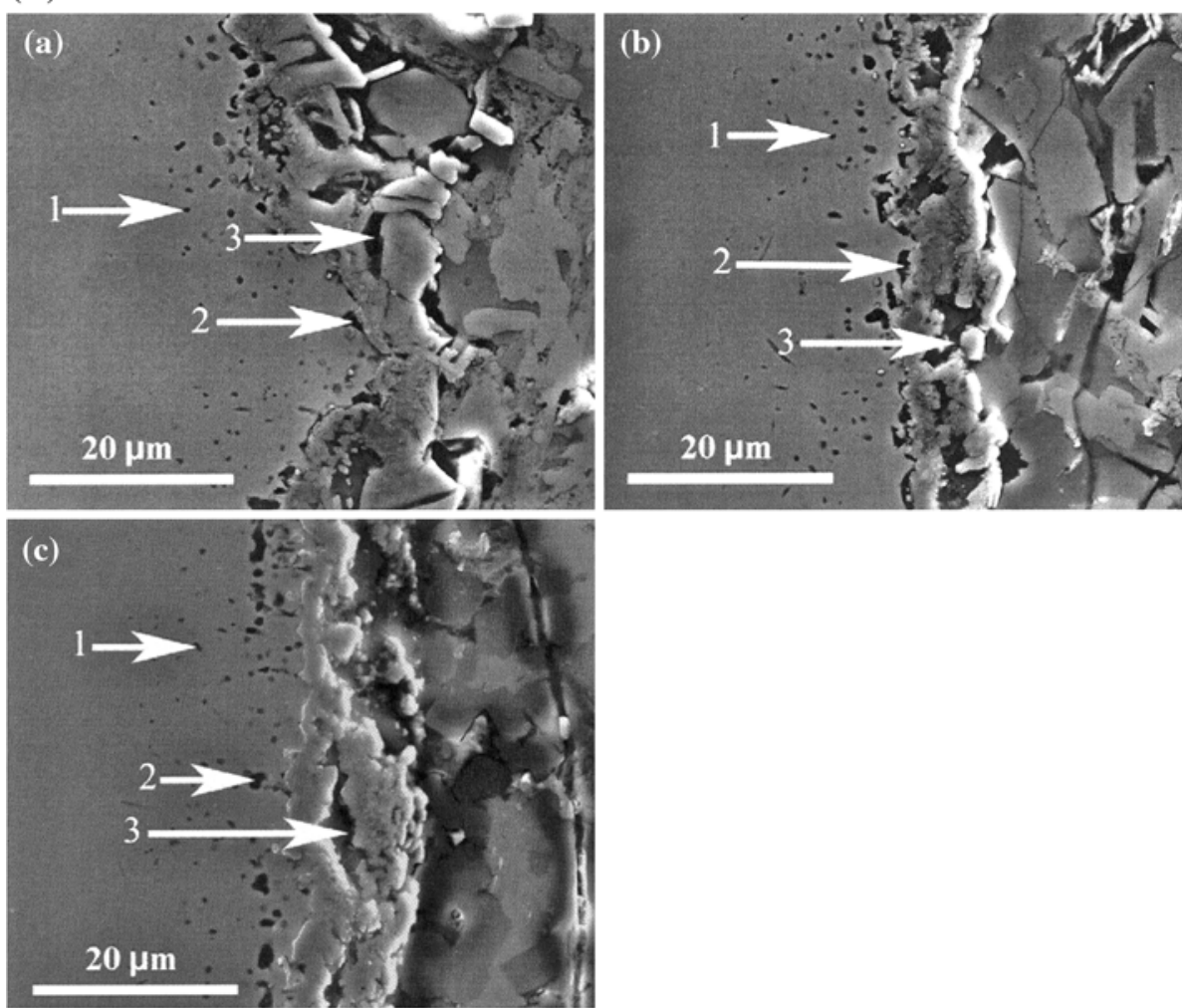

(D)
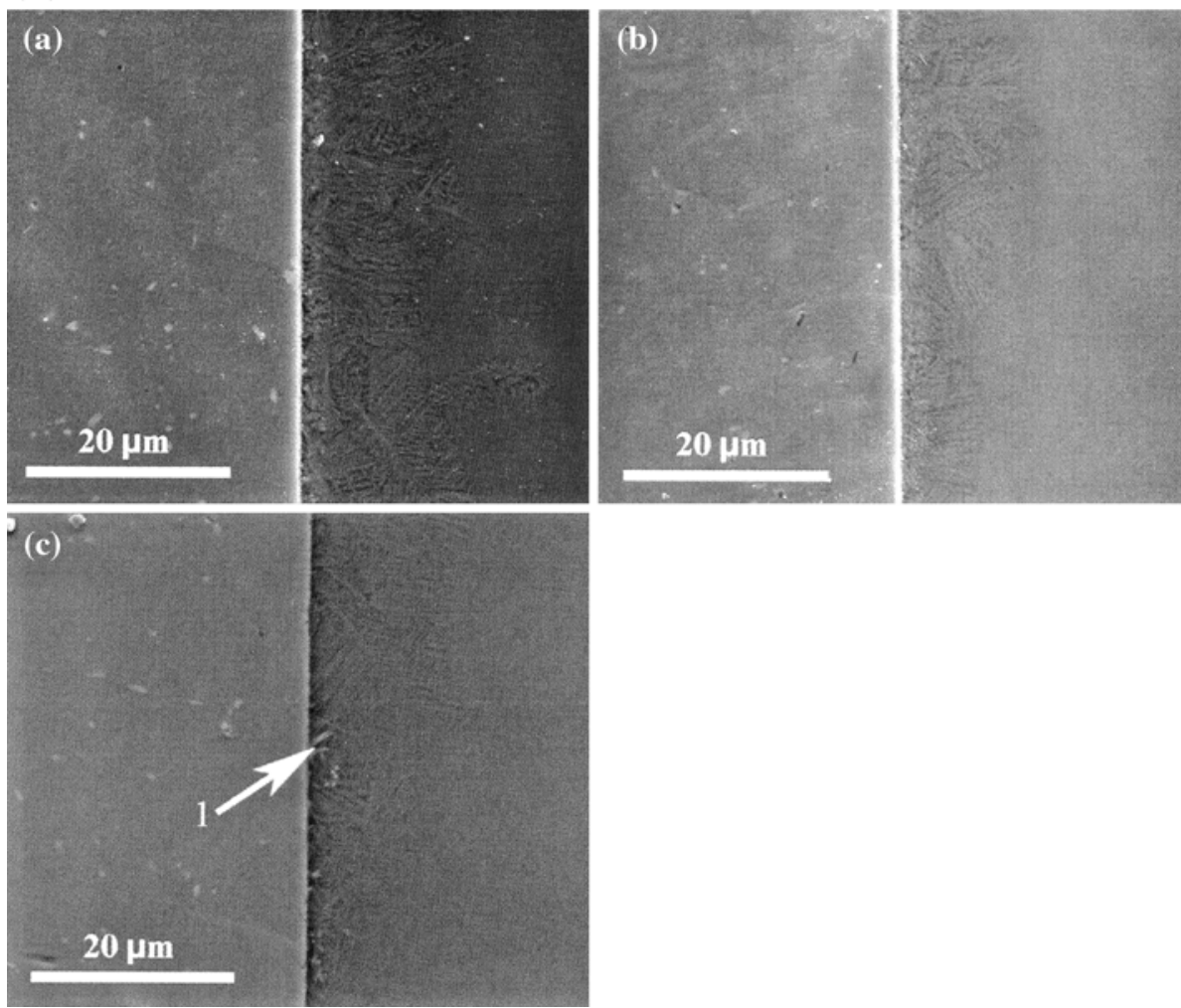

a thin coating of the Ti6Ti4V with a fluorapatite-mullite glass using EPD and sputtering [145-147]. The result was a stable, dense, adherent and homogeneous coating.
A sedimentation and heat treatment process was also used by Stanton et al. to coat $\mathrm{Ti}$ with a fluorapatite-mullite system [148]. A combination of SEM, TEM and selected 


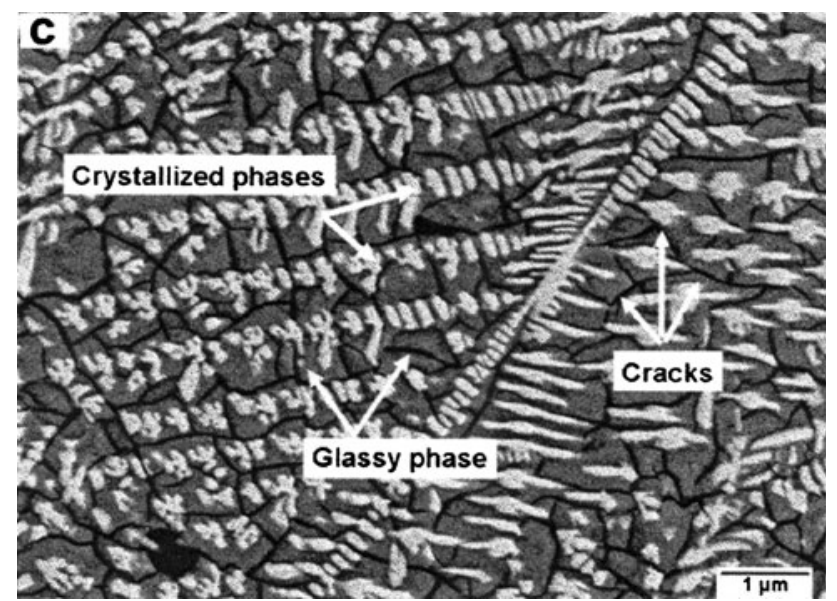

Fig. 13 Microstructure of glass-ceramic exhibiting cracking due to differential thermal expansion between different phases. Reprinted from Ghosh et al. [72], with permission from Elsevier

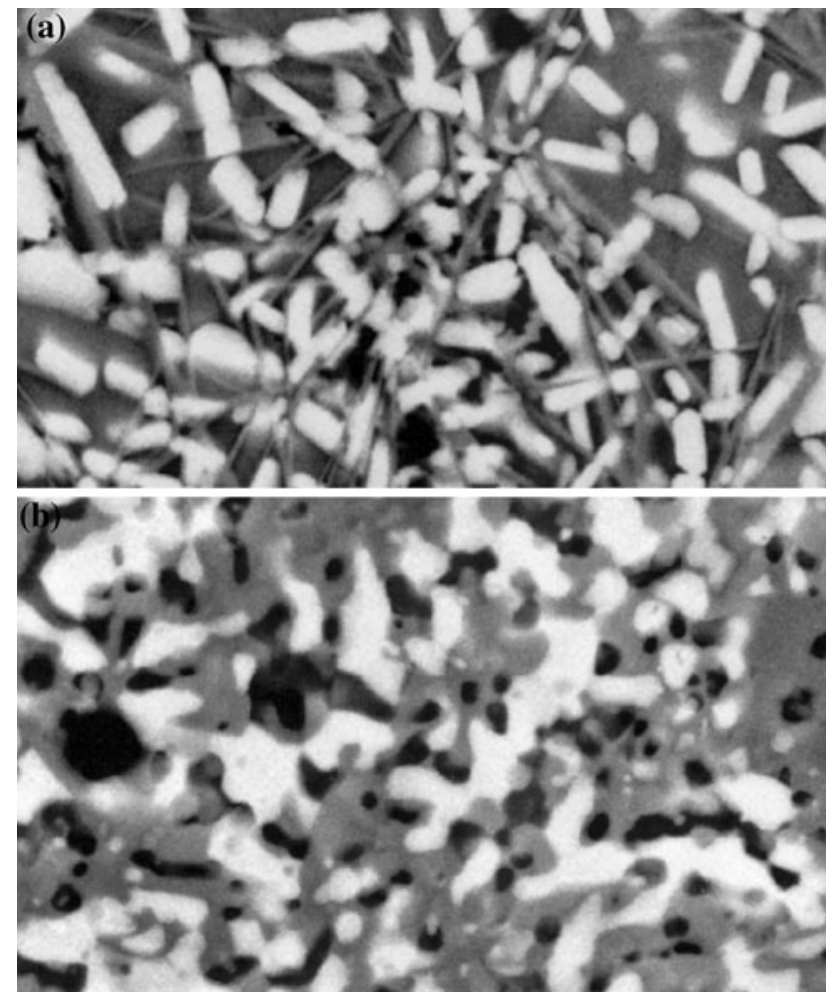

Fig. 14 Glass-ceramic before (a) and after (b) ageing at $750{ }^{\circ} \mathrm{C}$ for $1000 \mathrm{~h}$. Formation and coalescence of voids (black areas in the micrograph) up to around $2 \mu \mathrm{m}$ in size appear in the glass-ceramic after ageing. Reprinted from Stephens et al. [69], with permission from Elsevier

area diffraction was used to study the interfaces, which were found to be complex and non-planar and contain titanium silicide. A bioactive glass based on $\mathrm{MgO}-\mathrm{CaO}-$ $\mathrm{P}_{2} \mathrm{O}_{5}-\mathrm{SiO}_{2}$ was used to coat Ti by Mardare et al. [149] employing RF magnetron sputtering, followed by a heat treatment of $30 \mathrm{~min}$ at $950{ }^{\circ} \mathrm{C}$ to crystallize the glass. The
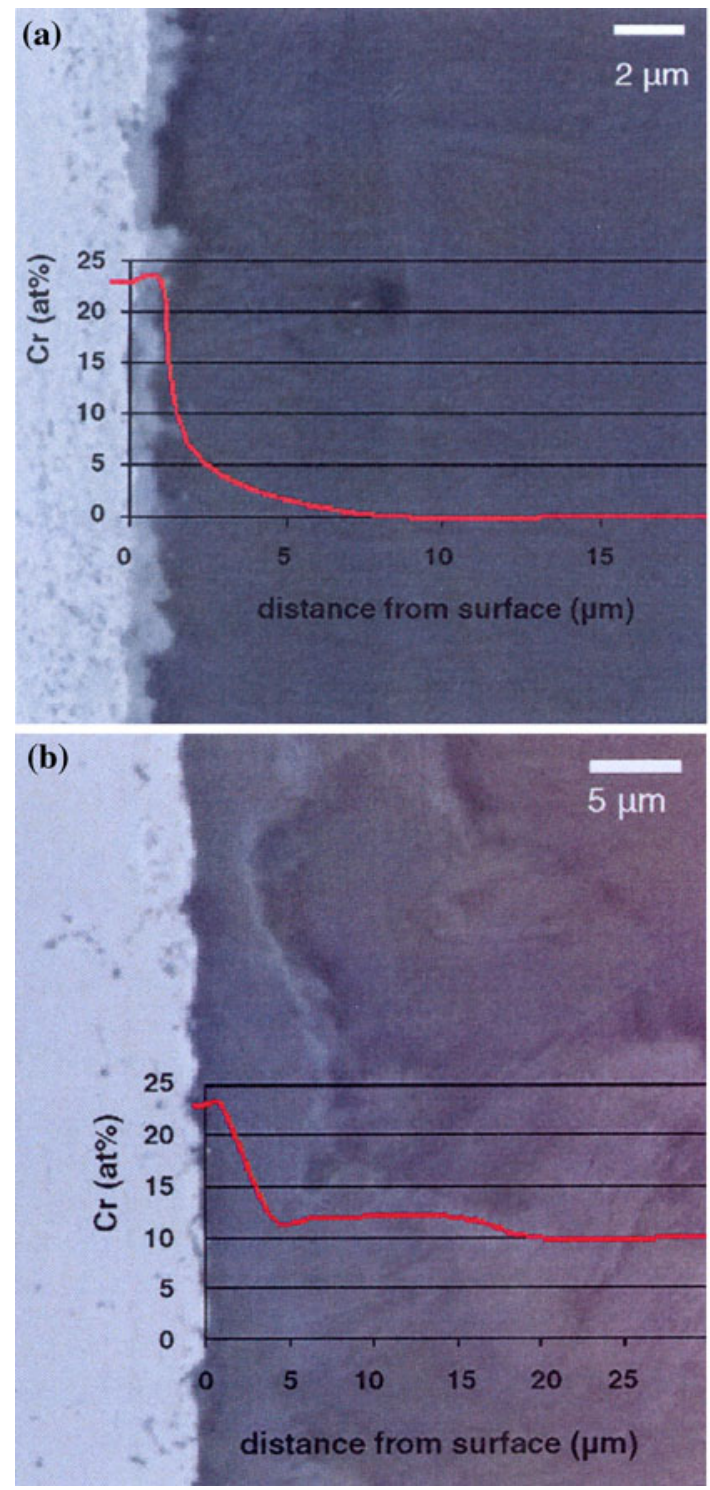

Fig. 15 Seal between Fe20Cr alloy and glass-ceramic with EDS line scan for Cr. a Pre-oxidized metal. b Unoxidized metal. Note diffusion of $\mathrm{Cr}$ into the glass-ceramic is greated in the case of the unoxidized sample. Reprinted from Smeacetto et al. [77], with permission from Elsevier

amorphous coating (prior to crystallization) gave better adhesion, cracking being evident from the SEM images after the crystallization step. Vitale-Brovarone and Verné coated Ti6Al4V alloy with a glass from the $\mathrm{SiO}_{2}-\mathrm{CaO}$ $\mathrm{K}_{2} \mathrm{O}$ system using a simple enamelling and glazing technique [150]. A short firing time was used to prevent over reaction at the interface. The highest quality coatings were obtained with a thermal treatment at $900{ }^{\circ} \mathrm{C}$ for $60 \mathrm{~s}$.

Double layer coating of Ti6Al4V alloy with a glass, glass-ceramic or hydroxyapatite particles has been reported by Garcia et al. [151]. They used a $\mathrm{CaO}-\mathrm{SiO}_{2}-\mathrm{P}_{2} \mathrm{O}_{5}$ glass system with a firing temperature of $1050{ }^{\circ} \mathrm{C}$ for $2 \mathrm{~h}$ to 


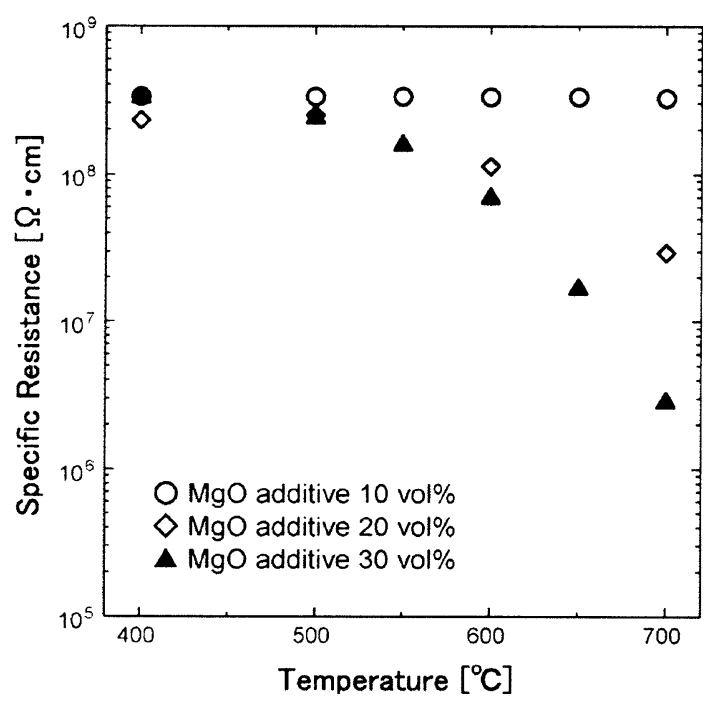

Fig. 16 Plot of specific electrical resistance against temperature for glass-MgO composite sealing medium. Reprinted from Sakuragi et al. [76], with permission from Elsevier

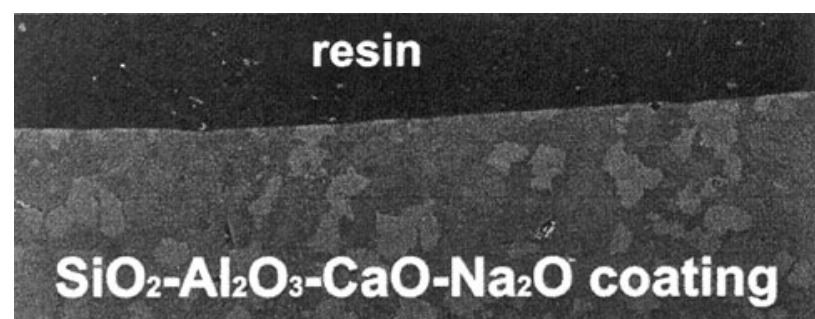

TIMETAL834

$100 \mu \mathrm{m}$

Fig. 17 Glass-ceramic coating on TIMETAL834 Ti alloy. Reprinted from Moskalewicz et al. [125], with permission from Elsevier

produce the glass-ceramic. Homogeneous, crack-free double-layer coatings were prepared first using the glass followed by either the glass-ceramic or hydroxyapatite. Schrooten and Helsen, Schrooten et al. and Helsen et al. have investigated using a bioactive glass $\left(\mathrm{SiO}_{2}-\mathrm{CaO}-\right.$ $\mathrm{Na}_{2} \mathrm{O}-\mathrm{P}_{2} \mathrm{O}_{5}-\mathrm{CaF}_{2}$ ) coating on Ti6Al4V alloy for potential applications as oral implants [152-154]. They used reactive plasma spraying to coat the alloy, a technique that transforms crystalline-based products into a glass coating. Adhesion tests showed the interface to remain intact after the coating had been crushed. It was concluded, therefore, that the interface was stronger than the bulk of the glass coating. Britchi et al. used simple enamelling techniques to successfully coat Ti with a calcium borosilicate glass [155]. In an attempt to improve the strength of the coating and its adherence to the substrate, $0.1-0.2$ mass $\%$ of Ti particles $20 \mu \mathrm{m}$ in size were added to the glass. Investigation of the properties of the modified coating noted some success. Kasuga et al. have reported coating an $\alpha$-alloy of $\mathrm{Ti}$ (Ti29Nb13Ta4.6Zr) with a calcium phosphate-based glassceramic $\left(60 \mathrm{CaO}-30 \mathrm{P}_{2} \mathrm{O}_{5}-3 \mathrm{TiO}_{2}-7 \mathrm{Na}_{2} \mathrm{O}\right)$ [156]. Heating at $800{ }^{\circ} \mathrm{C}$ for $60 \mathrm{~min}$ in air was used for joining, to give a tensile bonding strength of $\sim 20 \mathrm{MPa}$. SEM showed no serious cracks or defects in the coating; however, many pores of several micrometres in size were observed. In general, the use of silicate-based glasses has produced a wide variation in results, with reports in the literature ranging from no bond to very good bonding; however, the trends would appear to be relatively straightforward to explain. If the seal is produced at temperatures in excess of the $\alpha$-to- $\beta$-transition temperature, there is a high-probability of failure, due to the volume change during the transition and the formation of an excessively thick reaction layer of $\mathrm{Ti}_{5} \mathrm{Si}_{3}$. It should be noted that when modest temperatures (in the region of $800{ }^{\circ} \mathrm{C}$ ) and short sealing periods (less than a few minutes) are used, excellent results have been reported. This has been attributed to a thin reaction layer, which is consistent with the generally held theory that a thin layer of an intermetallic nature produces a transition in bond type between the metal and the glass/ ceramic.

Seals for high-performance electrical and electronic components

Both glass- and glass-ceramic-to-metal seals are employed in electrical feedthrough connectors for such applications as sensors, vacuum valves, transducers, microwave components, aircraft and spacecraft instruments, gyroscopes, engine control systems, high-pressure connectors, lightning arrestors, detonators and explosive actuators, batteries, biomedical components including heart pacemakers, lamps and lasers [1]. Coatings are also employed in electronic substrates. Most electronic packages employ glass-to-metal seals [1], although glass-ceramics may be used where a higher temperature capability is required. More recent work includes sealing of an alkali boroaluminosilicate glass to Kovar for use in MEMS (Micro-Electronics Mechanical Systems) packages [157].

Seals for battery applications

A number of different battery designs employ glass-tometal seals. These include $\mathrm{Na}-\mathrm{S}, \mathrm{Na}-\mathrm{SO}_{2}, \mathrm{Na}-$ alkali halide-S, Na-NiCl, Li-SO ${ }_{2}, \mathrm{Li}-\mathrm{SOCl}_{2}, \mathrm{Li}-\mathrm{MnO}_{2}, \mathrm{Li}-\mathrm{I}$ and $\mathrm{Li}-\mathrm{Cr}_{2} \mathrm{O}_{3}$ batteries [1]. $\mathrm{Na}-\mathrm{S}$ batteries are currently 
employed in many areas including power load-levelling applications at a number of Japanese power stations and as emergency power sources. Lithium batteries are also used in many applications from heart pacemakers and portable diagnostic equipment to electric vehicles.

The Na-S battery, for example, normally operates at $300-350{ }^{\circ} \mathrm{C}$, although lower operating temperatures are possible with some early designs [158], and utilizes a molten $\mathrm{Na}$ cathode and a molten $\mathrm{S}$ anode together with a solid $\beta$-alumina electrolyte, as reviewed by Oshima et al. [159]. The Na batteries require hermetic and corrosion resistant seals to provide containment for the molten materials and electrical isolation between the battery case and cathode. Early work included the use of sodium borosilicate glass compositions and glasses containing $\mathrm{CaO}, \mathrm{SrO}$ or $\mathrm{BaO}$ [160]. Silicate-based glasses are not, however, ideally suited to this application and are prone to reaction between the glass and $\mathrm{Na}$ to form electrically conducting silicide phases that lead to short battery lifetimes. Later work concentrated on silicate-free compositions including a sodium borate-based glass containing $\mathrm{Cs}_{2} \mathrm{O}$ [161] and alkaline earth aluminoborate compositions [88]. More recent work has returned to examine borosilicate-based glasses, with $\mathrm{Bi}_{2} \mathrm{O}_{3}$-doped borosilicate glass compositions showing particular promise [162], together with new glass-ceramic compositions [163]. The newer $\mathrm{Na}-\mathrm{NiCl}$ battery, which evolved from the earlier $\mathrm{Na}-\mathrm{S}$ battery, also utilizes a molten $\mathrm{Na}$ cathode but with an anhydrous solid $\mathrm{NiCl}$ anode [164], and this design also poses similar sealant compatibility issues.

Many of the Li batteries face similar problems in terms of compatibility between the glass sealants and battery components $[1,165]$. An early study of glass seal corrosion in, for example, $\mathrm{Li}-\mathrm{SOCl}_{2}$ batteries examined the compatibility of a number of commercial sealing glasses with stainless steel, Mo and $\mathrm{Fe}-\mathrm{Ni}$ alloys typically employed in battery construction [166]. It was found that glasses of high-silica content were particularly susceptible to glass corrosion, but that SNLA's TA-23 glass and Fusite's 402/ 425 low-silica glasses provided the most corrosion resistant seals.

Seals for other applications

Glass-to-metal seals are employed in solar absorber tubes, these being a major component in parabolic trough solar thermal power systems. The tubes convert the solar energy into thermal energy and comprise a coated metal pipe to absorb the heat, surrounded by an evacuated glass envelope with tubular end seals. A typical example is depicted in Fig. 18. Fracture of the glass-to-metal seals during service is the main cause of failure in these systems [167, 168]. Finite element analysis has been carried out for

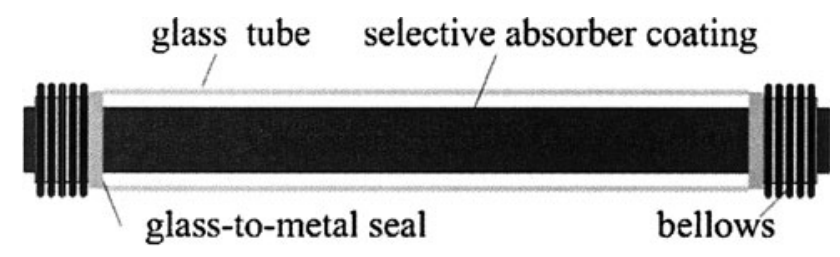

Fig. 18 Schematic illustration of solar absorber tube showing position of metal/glass seals. Reprinted from Lei et al. [167], with permission from Elsevier

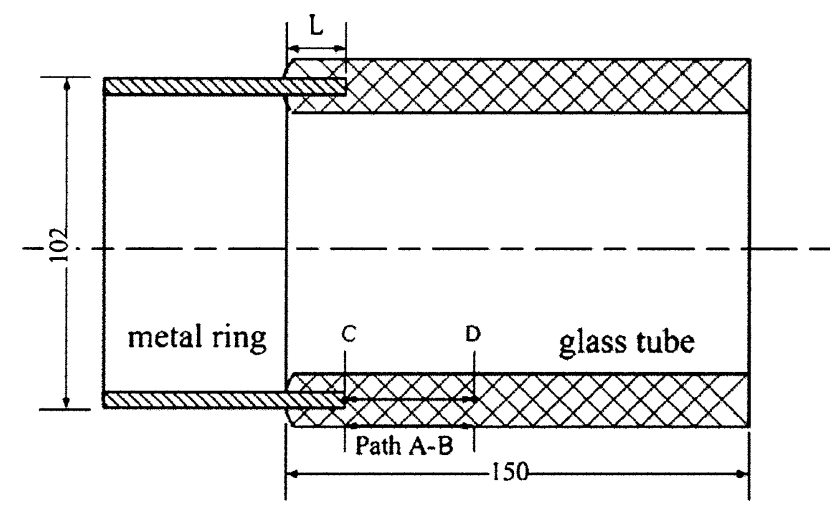

Fig. 19 Solar absorber tube seal geometry showing seal arrangement. Reprinted from Lei et al. [167], with permission from Elsevier

Kovar-to-Pyrex seals consisting a glass tube with outer diameter of $104 \mathrm{~mm}$, wall thickness $3 \mathrm{~mm}$ and length $150 \mathrm{~mm}$, to determine the stress distributions in the seals. Analysis has indicated that use of a metal ring with rounded rather than blunt ends or thinning of the metal in the seal area (classic Housekeeper seal) reduces the residual stresses in the seal. In addition, as illustrated in Fig. 19, the depth of embedded metal, $L$, should be kept less than $8 \mathrm{~mm}$ to minimize stresses.

\section{Recent fundamental studies}

Seals to pure metals, $\mathrm{Fe}, \mathrm{Ni}$ and $\mathrm{Cr}$

Little work has been reported on the sealing of glasses or glass-ceramics to the pure metals $\mathrm{Fe}, \mathrm{Ni}$ and $\mathrm{Cr}$, despite the fact that these metals are major constituents of many commercially important alloys, including stainless steels and Ni-based superalloys, although there is an early report on bonding to $\mathrm{Cr}$ [169]. This general lack of data for the pure metals makes it more difficult to identify the diffusion characteristics of individual metals without the complicating influence of multiple element diffusion. Studies on individual elements are therefore desirable to be able to characterize their independent behaviour.

In a recent investigation in this area [8,9], seals have been prepared between a LZS glass and high-purity $\mathrm{Fe}, \mathrm{Ni}$ 


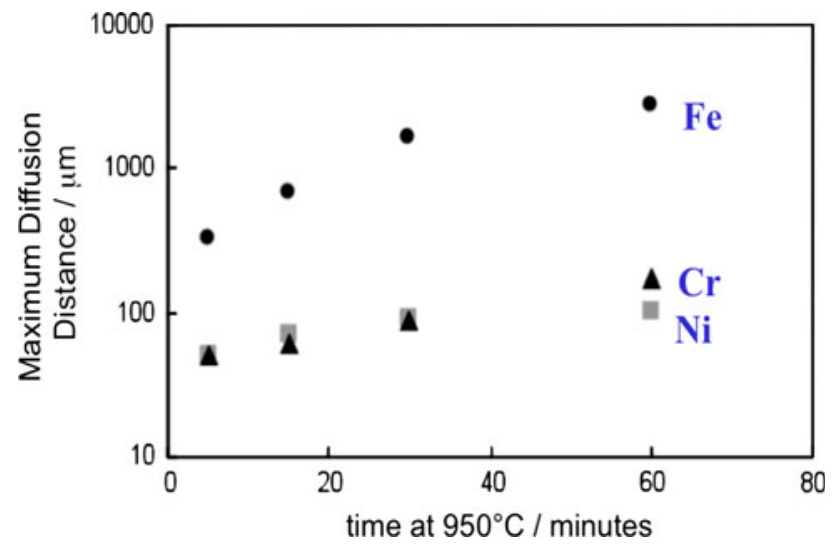

Fig. 20 Diffusion of $\mathrm{Fe}, \mathrm{Ni}$ and $\mathrm{Cr}$ in $\mathrm{Fe} / \mathrm{LZS}, \mathrm{Ni} / \mathrm{LZS}$ and $\mathrm{Cr} / \mathrm{LZS}$ glass-ceramic seals as a function of time at $950{ }^{\circ} \mathrm{C}$. Authors' data

and $\mathrm{Cr}$ metals, and the diffusion of these metals into the glass as a function of temperature and time and their effect on the crystallization behaviour monitored. Line scans and spot analyses were performed by EDS, from which the maximum depth of diffusion of each metallic element was estimated. Of the three metals investigated, the diffusion distance associated with $\mathrm{Fe}$ at the sealing temperature is very much greater than that of $\mathrm{Ni}$ or $\mathrm{Cr}$, as seen in Fig. 20. This strongly suggests that $\mathrm{Fe}$ is diffusing into the glass as $\mathrm{Fe}^{2+}$. On the other hand, $\mathrm{Cr}$ diffuses only a relatively short distance, suggesting that it is diffusing predominantly as $\mathrm{Cr}^{3+}$. No significant interfacial reactions were noted, as observed in Fig. 21; however, an interesting anomaly was found for some of the seals to $\mathrm{Cr}$ which were prepared by placing the seal assemblies on a $\mathrm{Cu}$ plate in the sealing furnace. In this instance, precipitates were observed along the interface, which were rich in $\mathrm{Cu}$ and $\mathrm{Zn}$, and the metal adjacent to the interface appeared porous, as observed in Fig. 22. Later seals were prepared on Pt, and no such reactions were observed.

\section{Seals to other metals}

Renewed interest has also recently been shown in LZS glass-ceramics for sealing applications [170, 171]. In these studies, it was confirmed that the thermal expansion of the glass-ceramics is dependent on the thermal cycle employed. For a cylinder/pin seal, it can be seen that extensive diffusion occurs on a macro scale around the copper pin, as noted in Fig. 23. New ferritic stainless steels have been developed for glass-to-metal sealing in which a double oxide layer consisting of $\mathrm{Cr}$-rich inner and spinelrich outer regions can be formed with good bonding characteristics to both substrate and glass [172]. Similar oxide layers can be formed on Hastelloy-XR alloy with good seals produced [173]. Anodic bonding of an alkali silicate glass containing small additions of $\mathrm{Al}_{2} \mathrm{O}_{3}, \mathrm{ZnO}$ and
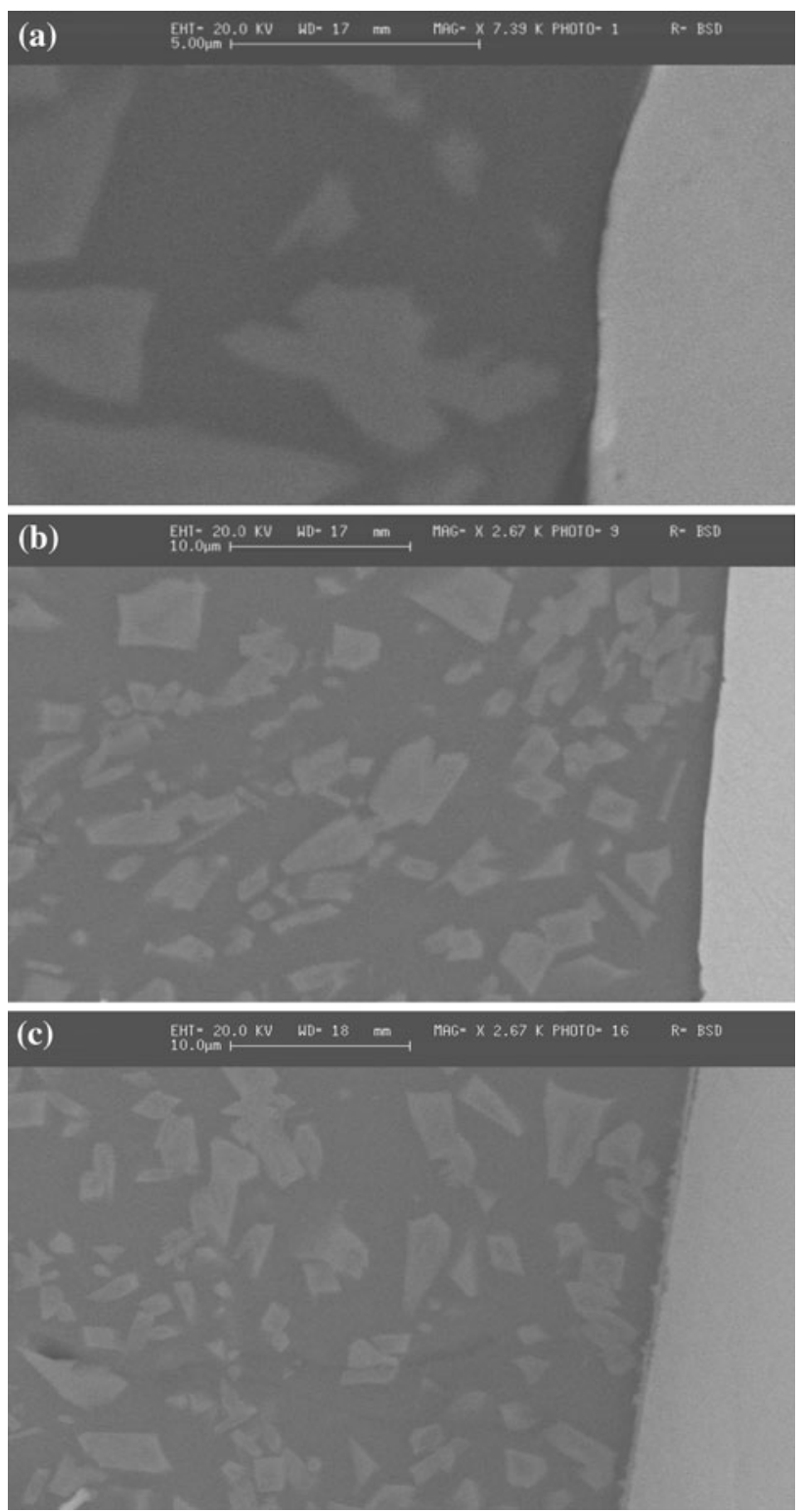

Fig. 21 Interfaces between pure metals and LZS glass-ceramic sealed at $950{ }^{\circ} \mathrm{C}$ for $15 \mathrm{~min}$. a To $\mathrm{Fe}, \mathbf{b} \mathrm{Ni}$ and $\mathbf{c ~} \mathrm{Cr}$

$\mathrm{P}_{2} \mathrm{O}_{5}$ to stainless steel for potential applications involving the encapsulation of sensors has also been reported recently [174].

\section{Discussion}

It is now well established that the starting glass composition and processing conditions exert a very strong influence on the properties of seals and coatings, with interfacial reactions playing a very important role. In the case of electrical feedthrough seals, it has been found that small additions of transition metal oxides to the starting glass can 


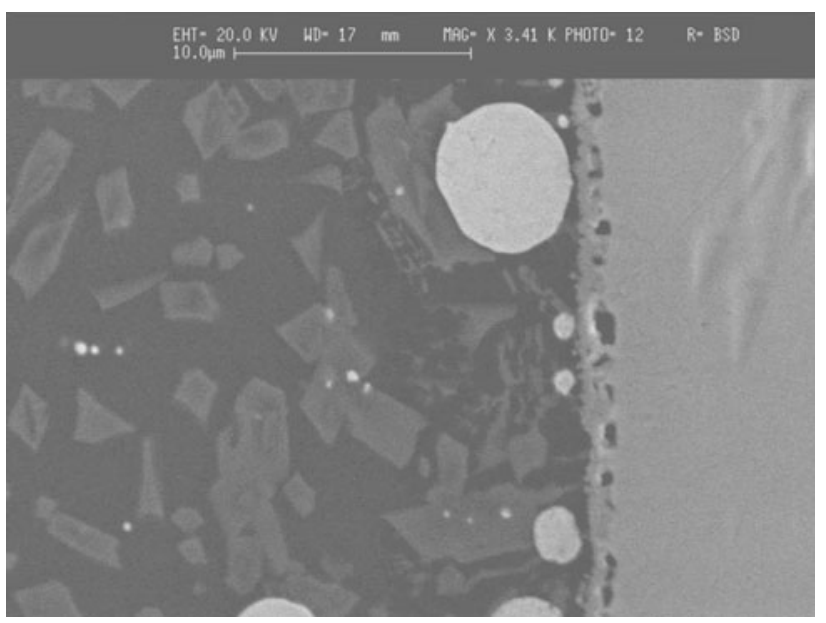

Fig. 22 Anomalous seal between Cr and LZS glass-ceramic showing the presence of $\mathrm{CuZn}$-rich precipitates along the interface

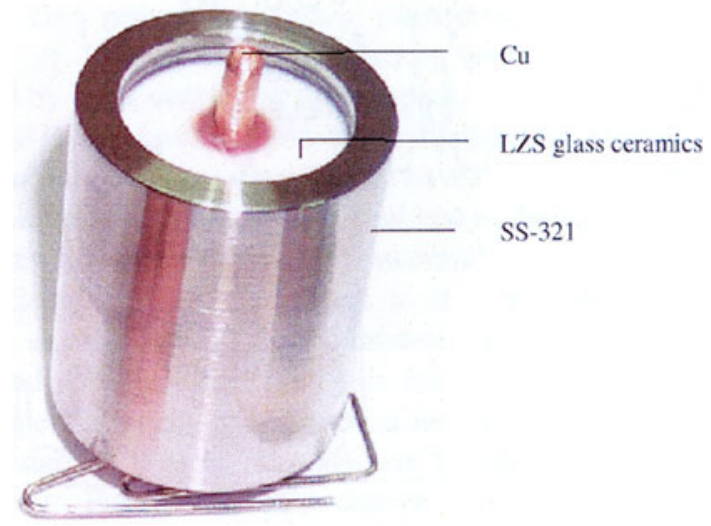

Fig. 23 Cylinder/pin seal between SS321 stainless steel/Cu pin and LZS glass-ceramic. Note the extensive diffusion region around the pin. Reprinted from Goswami et al. [171], with permission from Elsevier

influence seal quality by modifying interfacial reactions. Alternatively, pre-oxidation of the metal components can also influence seal quality by hindering the diffusion of metallic species into the interfacial zone, although it is essential that the appropriate substrate metal oxide is formed during the pre-oxidation stage, i.e. an oxide with low solubility and low diffusivity in the glass in question. The influence of pre-oxidation on metal diffusion characteristics has also been noted in the case of SOFC seals although, as noted, the oxidation state of the substrate oxide is critical. As also highlighted, self-healing of glassceramic seals in SOFC is an issue of topical interest, and successful application may facilitate longer fuel cell life in service. Other factors affecting seal quality include, of course, the surface cleanliness of the starting materials and the amount of water dissolved in the starting glass. A study of the influence of surface cleaning treatments and how these affect seal quality has, for example, been reported by Donald et al. [175].

When sealing to the pure unoxidized metals, extensive diffusion of $\mathrm{Fe}$ and to a lesser degree $\mathrm{Cr}$ into lithium zinc silicate glass has been observed, whilst Ni diffusion is less severe $[8,9]$. Noteworthy is the fact that there is little evidence for interfacial reactions in the case of pure $\mathrm{Fe}$ or $\mathrm{Ni}$ and only minor reaction for $\mathrm{Cr}$. This is in marked contrast to seals to the multi-component metal alloys, where reactions occurring in the vicinity of the interface are often far more extensive. The anomalous sealing behaviour noted for LZS seals to $\mathrm{Cr}$ when heat-treated in contact with copper, in which $\mathrm{CuZn}$-rich precipitates are formed at the $\mathrm{Cr} / \mathrm{glass}$ interface, suggests that reactions can occur between constituents of a glass and specific metal species in the presence of additional metal species, and this may explain the differences noted between sealing to pure metals and sealing to complex alloys $[8,9]$. The precise reason why these apparent differences occur is presently the subject of additional studies.

A large amount of work has been reported on the coating of bioactive silicate based glasses onto both $\mathrm{Ti}$ and Ti6Al4V alloy. The reactivity issues can be minimized by very strict control of the reaction conditions and use of short heating times in nitrogen. The optimum temperature to provide good wetting and avoid excessive interfacial reactions has been noted to be around $800-850{ }^{\circ} \mathrm{C}$. Good adhesion can be achieved using glasses with greater than $56 \mathrm{~mol} \% \mathrm{SiO}_{2}$, and these glasses also provide a reasonable match between the coefficients of thermal expansion, but undesirable interfacial reactions need to be avoided. On the other hand, many of the results using silicate-based glass-ceramics have been unsuccessful. This may be attributed not only to the difficulties associated with sealing to this reactive metal, but also in the case of glass-ceramics to the need to heat treat the glass to nucleate and crystallize it to form the glassceramic. This is likely to promote excessive amounts of reaction products at the interface. Other glass systems have been reported, which show considerable promise for sealing to Ti. The alkaline earth boroaluminate glasses, for example, may produce good quality seals that are significantly superior to silicate-based analogues. The coefficients of thermal expansion of these glasses are also similar to that of Ti metal and almost an exact match for the Ti6Al4V alloy. The use of calcium borosilicate and alkaline earth lanthanum borate glass has also been reported to produce good quality seals to Ti metal. The role played by the design of the test sample and final component is also of critical importance. In many cases reported in the literature, the test sample has been based on that required for sessile drop measurement, formed by placing the molten glass in direct contact with a flat plate, 
and in many cases this may result in the generation of tensile stresses and lead to misleading results.

There is every reason to believe that a "successful" bond can be produced between glasses and metals with judicious material selection and sample design, in combination with controlled sealing cycles. In conclusion, a thorough understanding of the interfacial reactions at a glass- or glass-ceramic-to-metal interface is required to create the conditions necessary to produce an acceptable seal. In addition, the importance of design should not be underestimated, with poor design usually associated with a mismatch in thermal expansion, consequently producing tensile stresses in the glass/ceramic component. A successful design seeks to place the interface in compression in addition to avoiding stress concentrating influences as associated, for example, with poor geometrical design. When designing components, it is therefore essential to understand the relationship between the physical properties of the bulk materials, the potential for any interfacial reactions, the final stress state of the bonded component, and how these may be affected by the operating conditions of the final component during service.

\section{Conclusions}

1. There has been a recent, strong revival of interest in glass- and glass-ceramic-to-metal seals and coatings, driven, for example, by the requirements for improved SOCF seals and coatings for biomedical implants.

2. Glass-ceramics are versatile materials whose properties, in particular thermal expansion, can be tailored, thus making them ideally suited to applications requiring specific thermal expansion characteristics including bonding to a wide variety of metals and alloys.

3. To ensure confidence in an adequate component life, interfacial reactions and diffusion of both metallic and glass species must be minimized.

4. The drive towards the development of a superior seal for SOFCs continues, with many new glass compositions investigated and with the issue of self-healing being of topical interest.

5. A comparison between sealing to pure metals and multi-component alloys highlights differences in the behaviour and suggests that it is more likely for deleterious reactions to occur in alloy systems. For particular metallic species such as $\mathrm{Fe}$ or $\mathrm{Cr}$, this may be due to the influence of additional metal species in the interfacial zone, these helping to promote these reactions. Deleterious reactions can, nevertheless, be minimized through careful control of the processing conditions or starting glass composition.
Acknowledgement C British Crown Owned Copyright 2010/MOD.

\section{References}

1. Donald IW (2007) Glass-to-metal seals. Society of Glass Technology, Sheffield (Amazon edition, 2009)

2. McMillan PW, Hodgson BP (1963) Engineering 196:366

3. McMillan PW (1979) Glass-ceramics, 2nd edn. Academic Press, London

4. Höland W, Beall G (2002) Glass-ceramic technology. American Ceramic Society, Westerville, $\mathrm{OH}$

5. Donald IW (1993) J Mater Sci 28:2841. doi:10.1007/BF00354689

6. Partridge JH (1949) Glass-to-metal seals. Society of Glass Technology, Sheffield

7. Fernie JA, Hanson WB (1999) Ind Ceram 19:172

8. Donald IW, Metcalfe BL, Gerrard LA, Fong SK (2006) Adv Sci Technol 45:1520

9. Donald IW, Metcalfe BL, Gerrard LA (2008) J Am Ceram Soc 91:715

10. Haws LD, Kramer DP, Moddeman WE, Wooten GW (1995) High strength glass-ceramic-to-metal seals. Technical Report MLM-3288(OP)

11. Andrews AI (1961) Porcelain enamels: the preparation, application, and properties of enamels, 2nd edn. Garrard Press, Champaign, IL

12. Holland D (1995) Key Eng Mater 99-100:203

13. Hong F, Holland D (1989) J Non-Cryst Solids 112:357

14. Polmear IJ (1995) Light alloys: metallurgy of the light metals. Arnold, London

15. Jackson M (2007) Mater World $15: 32$

16. Yamada M (1996) Mater Sci Eng 8:213

17. Michaelis A, Kudelka S, Schultze JW (1989) Electrochim Acta 43:119

18. Benjamin D (1980) Metals handbook, vol 3, 9th edn. American Society for Metals, Metals Park, OH

19. Dobbs HS (1982) J Mater Sci 17:2398. doi:10.1007/BF0054 3750

20. Goldstein JI, Choi SK, Vanloo FJJ, Bastin GF, Metselaar R (1995) J Am Ceram Soc 78:313

21. Passerone A, Valbusa G, Biagini E (1977) J Mater Sci 12:2465. doi:10.1007/BF00553934

22. McColm IJ, Dimbylow C (1974) J Mater Sci 9:1320. doi: 10.1007/BF00551850

23. Sitnikova AY, Appen AA, Anitov IS, Fedorov VN, Kalinina AM, Piryutko MM (1974) J Appl Chem USSR 47:1981

24. Hong F (1990) PhD thesis, University of Warwick

25. Holland D, Fong F, Logan E, Sutherland S (1990) Glass-ceramic coatings for extended performance. Institute of physics conference series no. 111 , pp 459-468

26. Hong F, Holland D (1989) Surf Coat Technol 39(40):19

27. Donald IW, Metcalfe BL, Bradley DJ, Battersby SE (1994) In: Vincezini P (ed) Proceedings of 8th CIMTEC world ceramics congress, ceramics: charting the future, Florence, Italy, pp 2239-2246

28. Brow RK, Watkins RD (1987) In: Moddeman WE et al (eds) Technology of glass, ceramic and glass-ceramic-to-metal sealing. American Society of Mechanical Engineers, New York, pp 25-30

29. Brow RK (1993) Join Adhes Adv Inorg Mater 314:77

30. Bloyer DR, Gomez-Vega JM, Saiz E, McNaney JM, Cannon RM, Tomsia AP (1999) Acta Mater 47:4221

31. Pazo A, Saiz E, Tomsia AP (1998) Acta Mater 46:2551

32. Pazo A, Saiz E, Tomsia AP (1996) In: Tomsia AP, Glaeser AM (eds) Ceramic microstructures. Plenum Press, New York 
33. Gomez-Vega JM, Saiz E, Tomsia AP (1999) J Biomed Mater Res 46:549

34. Saiz E, Gomez-Vega JM, Tomsia AP (1999) http://escholarship. org/uc/item/4nf1s8vv (Internet Article)

35. Lopez-Esteban S, Saiz E, Fujino S, Oku T, Suganuma K, Tomsia AP (2003) J Eur Ceram Soc 23:2921

36. Gomez-Vega JM, Hozumi A, Saiz E, Tomsia AP, Sugimura H, Takai O (2001) J Biomed Mater Res 56:382

37. Kirkpatrick CW (1981) Metals handbook, vol 4, 9th edn. American Society for Metals, Metals Park, OH

38. Johnson CH, Richter SK, Hamilton CH, Hoyt JJ (1993) Acta Mater 47:23

39. Gomez-Vega JM (2000) Adv Mater 12:894

40. Chalker PR, Bull SJ, Rickerby DS (1991) Mater Sci Eng 140:583

41. Leedecke CJ, Baca HK (1979) Glass-ceramics for sealing to Pd-Ag alloys. Sandia Laboratories Report SAND79-0248

42. Sammes NM, Du Y (2007) Int J Appl Ceram Technol 4:89

43. Kendall K (2010) Int J Appl Ceram Technol 7:1

44. Chou Y-S, Stevenson JW (2004) In: Proceedings of joining of advanced and speciality materials, October 18-20. ASM International, Columbus, OH, pp 132-139

45. Mahapatra MK, Lu K (2010) Mater Sci Eng R 67:65

46. Jiang W, Tu ST, Li GC, Gong JM (2010) J Power Sources 195:3513

47. Steele BCH, Heinzel A (2001) Nature 414:345

48. Fergus JW (2005) J Power Sources 147:46

49. Reis ST, Brow RK (2006) J Mater Eng Perform 15:410

50. Lessing PA (2007) J Mater Sci 42:3465. doi:10.1007/s10853006-0409-9

51. Singh RN (2007) Int J Appl Ceram Technol 4:134

52. Kilner J, Edwards P, Kuznetsov V (2009) Mater World 17:36

53. Singh P, Minh NQ (2004) Int J Appl Ceram Technol 1:5

54. Weil KS, Coyle CA, Hardy JS, Kim JY, Xia G-G (2004) Fuel Cell Bull 2004:11

55. Weil KS (2006) The state-of-the-art in sealing technology for solid oxide fuel cells. JOM 58:37

56. Steinberger-Wilckens R, Blum L, Buchkremer H-P, Gross S, de Haart L, Hilpert K, Nabielek H, Quadakkers W, Riesgen U, Steinbrecht RW, Tietz F (2006) Int J Appl Ceram Technol 3:470

57. Tucker MC (2010) J Power Sources 195:4570

58. Menzler NH, Tietz F, Uhlenbruck S, Buchkremer HP, Stöver D (2010) J Mater Sci 45:3109. doi:10.1007/s10853-0104279-9

59. Sohn S-B, Choi S-Y, Kim G-H, Song H-S-, Kim G-D (2004) J Am Ceram Soc 87:254

60. Meinhardt K, Kim D-S, Yang G, Weil KS (2004) In: Proceedings of joining of advanced and speciality materials, October 18-20. ASM International, Columbus, OH, pp 124-131

61. Kharton VV, Tsipis EV, Carvalho AP, Kovalevsky AV, Naumovich EN, Marques FMB, Frade JR, Shaula AL (2005) In: Sammes N et al (eds) Fuel cell technologies: state and perspectives. Springer, Berlin, pp 231-238

62. Pascual J, Guillet A, Durán A (2007) J Power Sources 169:40

63. Wang R, Lu Z, Liu C, Zhu R, Huang X, Wei B, Ai N, Su W (2007) J Alloys Compd 423:189

64. Jinhua P, Kening S, Naiqing Z, Xinbing C (2007) J Rare Earths 25:434

65. Zhang T, Fahrenholtz WG, Reis ST, Brow RK (2008) J Am Ceram Soc 91:2564

66. Goel A, Tulyaganov DU, Kharton VV, Yaremchenko AA, Ferreira JMF (2008) Acta Mater 56:3065

67. Ghosh S, Das Sharma A, Kundu P, Mahanty S, Basu RN (2008) J Non-Cryst Solids 354:4081

68. Meinhardt KD, Kim D-S, Y-S Chou, Weil KS (2008) J Power Sources 182:188
69. Stephens EV, Vetrano JS, Koeppel BJ, Chou Y, Sun X, Khaleel MA (2009) J Power Sources 193:625

70. Goel A, Tulyaganov DU, Kharton VV, Yaremchenko AA, Eriksson S, Ferreira JMF (2009) J Power Sources 189:1032

71. Wang S-F, Wang Y-R, Hsu Y-F, Chuang C-C (2009) J Hydrog Energy 34:8235

72. Ghosh S, Sharma AD, Mukhopadhyay AK, Kundu P, Basu RN (2010) J Hydrog Energy 35:272

73. Sun T, Xiao H, Guo W, Hong X (2010) Ceram Int 36:821

74. Goel A, Tulyaganov DU, Ferrari AM, Shaaban ER, Prange A, Bondioli F, Ferreira JMF (2010) J Am Ceram Soc 93:830

75. Reis ST, Brow RK (2004) In: Proceedings of joining of advanced and speciality materials, October 18-20. ASM International, Columbus, OH, pp 119-123

76. Sakuragi S, Funahashi Y, Suzuki T, Fujishiro Y, Awano M (2008) J Power Sources 185:1311

77. Smeacetto F, Salvo M, Ferraris M, Cho J, Boccaccini AR (2008) J Eur Ceram Soc 28:61

78. Smeacetto F, Salvo M, Ferraris M, Casalegno V, Asinari P, Chrysanthou A (2008) J Eur Ceram Soc 28:2521

79. Kumar V, Arora A, Pandey OP, Singh K (2008) Int J Hydrog Energy 33:434

80. Smeacetto F, Chrysanthou A, Salvo M, Zhang Z, Ferraris M (2009) J Power Sources 190:402

81. Goel A, Tulyaganov DU, Kharton VV, Yaremchenko AA, Ferreira JMF (2010) J Power Sources 195:522

82. Smeacetto F, Salvo M, D'Hérin Bytner FD, Leone P, Ferraris M (2010) J Eur Ceram Soc 30:933

83. Milhans J, Khaleel M, Sun X, Tehrani M, Al-Haik M, Garmestani H (2010) J Power Sources 195:3631

84. Liu WN, Sun X, Koeppel B, Stephens E, Khaleel MA (2010) Int J Appl Ceram Technol

85. Mahapatra MK, Lu K (2010) J Am Ceram Soc. doi:10.1111/ j.1551-2916.2010.04020.x

86. Goel A, Pascual MJ, Ferreira JMF (2010) Int J Hydrog Energy 35:6911

87. Chou Y-S, Stevenson JW, Xia G-G, Yang Z-G (2010) J Power Sources 195:5666

88. Brow RK, Tallant DR (1997) J Non-Cryst Solids 222:396

89. Goel A, Tulyaganov DU, Pascual MJ, Shaaban ER, Muñoz F, Lü Z, Ferriera JMF (2010) J Non-Cryst Solids 356:1070

90. Brochu M, Gauntt BD, Shah R, Miyake G, Loehman RE (2006) J Eur Ceram Soc 26:3307

91. Mahapatra MK, Lu K, Reynolds WT (2008) J Power Sources 179:106

92. Laorodphan N, Namwong P, Thiemsorn W, Jaimasith M, Wannagon A, Chairuangsri T (2009) J Non-Cryst Solids 355:38

93. Widgeon SJ, Corral EL, Spilde MN, Loehman RE (2009) J Am Ceram Soc 92:781

94. Choi SR, Bansal NP, Garg A (2007) Mater Sci Eng A 460-461:509

95. Brochu M, Gaunt BD, Shah R, Loehman RE (2006) J Am Ceram Soc 89:810

96. Suda S, Matsumiya M, Kawahara K, Jono K (2010) Int J Appl Ceram Technol 7:49

97. Deng X, Duquette J, Petric A (2007) Int J Appl Ceram Technol 4:145

98. Story C, Lu K, Reynolds WT, Brown D (2008) Int J Hydrog Energy 33:3970

99. Yang Z, Stevenson JW, Meinhardt KD (2003) Solid State Ionics 160:213

100. Tu H, Stimming U (2004) J Power Sources 127:284

101. Haanappel VAC, Shemet V, Gross SM, Koppitz Th, Menzler NH, Zahid M, Quadakkers WJ (2005) J Power Sources 150:86

102. Menzler NH, Sebold D, Zahid M, Gross SM, Koppitz T (2005) J Power Sources 152:156 
103. Batfalsky P, Haanappel VAC, Malzbender J, Menzler NH, Shemet V, Vinke IC, Stenbrech RW (2006) J Power Sources 155:128

104. Nguyen BN, Koeppel BJ, Ahzi S, Khaleel MA, Singh P (2006) J Am Ceram Soc 89:1358

105. Liu W, Sun X, Khaleel MA (2008) J Power Sources 185:1193

106. Chou Y-S, Stevenson JW, Singh P (2008) J Power Sources 184:238

107. Zhang T, Zhu Q, Xie Z (2009) J Power Sources 188:177

108. Peng L, Zhu Q (2009) J Power Sources 194:880

109. Salem J, Tandon R (2010) Int J Fatigue 32:557

110. Liu WN, Sun X, Koeppel B, Khaleel M (2010) Int J Appl Ceram Technol 7:22

111. Milhans J, Li D, Khaleel M, Sun X, Garmestani H (2010) J Power Sources 195:5726

112. Chang H-T, C-K Lin, Liu C-K (2010) J Power Sources 195:3159

113. Jin T, Lu K (2010) J Power Sources 195:195

114. Jin T, Lu K (2010) J Power Sources 195:4853

115. Mahapatra MK, Lu K (2010) Int J Appl Ceram Technol 7:10

116. Liu WN, Sun X, Khaleel MA (2010) J Power Sources 196:1750

117. Zhang T, Tang D, Yang H (2011) J Power Sources 196:1321

118. Mahapatra MK, Lu K, Liu X, Wu J (2010) Int J Hydrog Energy 35:7945

119. Choi JP, Weil KS, Chou YM, Stevenson JW, Yang ZG (2010) Int J Hydrog Energy. doi:10.1016/ijhydene.2010.04.110

120. Schott Product Information (2009) Glass and glass ceramic sealants for solid oxide fuel cells, 10090.3. www.schott.com/ epackaging/english/download/online_schott_db_solid_oxide_ fuel_cells_rz_d_03_04.pdf

121. Datta S, Das S (2005) Bull Mater Sci 28:689

122. Das S, Datta S, Basu D, Das GC (2009) Ceram Int 35:1403

123. Das S, Datta S, Basu D, Das GC (2009) Ceram Int 35:2123

124. Yilmaz S, Bayrak G, Sen S, Sen U (2006) Mater Des 27:1092

125. Moskalewicz T, Smeacetto F, Czyrska-Filemonowicz A (2009) Surf Coat Technol 203:2249

126. Bengisu M, Brow RK, White JE (2004) J Mater Sci 39:605. doi: 10.1023/B:JMSC.0000011517.36767.a0

127. Moskalewicz T, Smeacetto F, Cempura G, Ajitdoss LC, Salvo M, Czyrska-Filemonowicz A (2010) Surf Coat Technol 204:3509

128. Sommers A, Wang Q, Han X, T'Joen C, Park Y, Jacobi A (2010) Appl Therm Eng 30:1277

129. Roessler S, Zimmermann R, Scharnweber D, Werner C, Worch H (2002) Colloids Surf B 26:387

130. Saiz E, Goldman M, Gomez-Vega JM, Tomsia AP, Marshall GW, Marshall SJ (2002) Biomaterials 23:3749

131. Donath K (1990) In: Osseo-integrated implants, vol 1. CRC Press, Boca Raton, FL

132. Kay JF (1992) Dent Clin N Am 36:11

133. Verné E, Vallés CF, Brovarone CV, Spriano S, Moisescu C (2004) J Eur Ceram Soc 24:2699

134. Pavon J (2006) J Eur Ceram Soc 26:1159

135. Pavon J (2006) Acta Mater 54:3593

136. Pavón J, Jiménez-Piqué E, Anglada M, Saiz E, Tomsia AP (2006) J Mater Sci 41:5134. doi:10.1007/s10853-006-0439-3

137. Pavon J, Caillate M, Jimenez-Pique E, Anglada M, LopezEsteban S, Saiz E, Tomsia AP (2005) Funct Graded Mater VIII 229:492

138. Stojanovic D, Jokic B, Veljovic D, Petrovic R, Uskokovic PS, Janackovic D (2007) J Eur Ceram Soc 27:1595

139. Sarkar P, Nicholson PS (1996) J Am Ceram Soc 79:1987
140. Lazic MS, Miskovic-Stankovic VB, Janackovic DT, Petrovic RD, Pavlovic LM (2004) Progr Adv Mater Process 453-454: 349

141. Tanaskovic D, Jokic B, Socol G, Popescu A, Mihailescu IN, Petrovic R, Janackovic D (2007) Appl Surf Sci 254:1279

142. Kulinich EA (2007) Glass Ceram 64:143

143. Cannillo V, Colmenares-Angulo J, Lusvarghi L, Pierli F, Sampath S (2009) J Eur Ceram Soc 29:1665

144. Li SJ, Niinomi M, Akahori T, Kasuga T, Yang R, Hao YL (2004) Biomaterials 25:3369

145. Bibby J, Mummery PM, Bubb N, Wood DJ (2004) Bioceramics 16(254-256):335

146. Bibby JK, Bubb NL, Wood DJ, Mummery PM (2005) J Mater Sci Mater Med 16:379

147. Bibby JK, Mummery PM, Bubb N, Wood DJ (2004) Glass Technol 45:80

148. Stanton KT, O'Flynn KP, Newcomb S (2008) Bioceramics 20(Pts1 and 2):269, 361

149. Mardare CC, Mardare AI, Fernandes JRF, Joanni E, Pina SCA, Fernandes MHV, Correia RN (2003) J Eur Ceram Soc 23:1027

150. Vitale-Brovarone C, Verne E (2005) J Mater Sci Mater Med $16: 863$

151. Garcia C, Cere S, Duran A (2006) J Non-Cryst Solids 352:3488

152. Schrooten J, Helsen JA (2000) Biomaterials 21:1461

153. Schrooten J, Van Oosterwyck H, Vander Sloten J, Helsen JA (1999) J Biomed Mater Res 44:243

154. Helsen JA, Proost J, Schrooten J, Timmermans G, Brauns E, Vanderstraeten J (1997) J Eur Ceram Soc 17:147

155. Britchi M, Jitianu G, Olteanu M, Crisan D, Marcu A, Nita P (2002) In: Sudarshan TS et al (eds) Surface modification technologies XV. ASM International/IOM Communications Ltd., Materials Park, OH/UK, pp 299-306

156. Kasuga T, Masayuki N, Niinomi M (2001) Key Eng Mater 192-195:223

157. Chern T-S, Tsai H-L (2007) Mater Chem Phys 104:472

158. Sklarchuck JC (1976) US Patent 3,988,163

159. Oshima T, Kajita M, Okuno A (2004) Int J Appl Ceram Technol 1:269

160. Park D-S, Navias L (1981) US Patent 4,268,313

161. Megerle CA (1992) US Patent 5,158,840

162. Song S, Wen Z, Zhang Q, Liu Y (2010) J Power Sources 195:466

163. Song S, Wen Z, Liu Y, Lin J, Xu X, Zhang Q (2010) J Solid State Electrochem 14:1735

164. Sudworth JL (2001) J Power Sources 100:149

165. Daniel C (2008) JOM 60:43

166. O'Hara TJ (1988) Proceedings of 33rd international power sources symposium. The Electrochemical Society, pp 262-273

167. Lei D, Wang Z, Li J (2010) Renew Energy 35:405

168. Lei D, Wang Z, Li J (2010) Mater Des 31:1813

169. Tomsia AP, Zhang F, Pask JA (1985) J Am Ceram Soc 68:20

170. Sharma BI, Goswami M, Sengupta P, Shrikhande VK, Kale GB, Kothiyal GP (2004) Mater Lett 58:2423

171. Goswami M, Sengupta P, Sharma K, Kumar R, Shrikhande VK, Ferreira JMF, Kothiyal GP (2007) Ceram Int 33:863

172. Mantel M (2000) J Non-Cryst Solids 273:294

173. Tu R, Goto T (2003) J Mater Sci Technol 19:19

174. Xiong D, Cheng J, Li H, Deng W, Ye K (2010) Microelectron Eng 87:1741

175. Donald IW, Metcalfe BL, Greedharee RS (2004) Proceedings of $\mathrm{XX}$ international congress on glass, Kyoto, Japan 